\title{
How to Tell the History of Business Ethics*
}

\section{GABRIEL ABEND ${ }^{* *}$}

The history of U.S. business ethics and CSR exhibits some key normative continuities and stability. I argue that these normative continuities and stability are underlain by moral background discontinuities and variation. The former I call "first-order" stability and the latter I call "second-order" variation. The second-order or moral background level is where the action is - at least, the action that sheds most light on our understanding of society, morality, and the moral foundations of capitalist societies. Next, I consider one facet of the moral background that might be of special interest to business ethics and CSR scholars: the demarcation of morality. How are boundaries between moral and non-moral things drawn? How are they institutionalized and policed? How do they vary across time and place? However, I also show why these empirical questions are conceptually trickier than they may appear at first sight.

Keywords: Business Ethics, CSR, Moral Background, Demarcation, History

\section{Wie die Geschichte der Unternehmensethik erzählt w erden soll}

\begin{abstract}
Die Geschichte der U.S.-amerikanischen Unternehmensethik und CSR weist einige wichtige normative Kontinuitäten und Stabilitäten auf. Ich argumentiere, dass diese normative Kontinuitäten und Stabilitäten mit Diskontinuitäten und Variationen eines moralischen Hintergrunds unterlegt sind. Erstere nenne ich Stabilitäten ,erster Ordnung", letztere V ariationen , zweiter Ordnung". Die Ebene zweiter Ordnung oder des moralischen Hintergrunds ist der Ort des Geschehens - zumindest desjenigen Ge-
\end{abstract}

The manuscript was submitted on 19.09.2015.

Thanks to sfwu editors T. Beschorner and T. Hajduk, managing editor D. Sindermann, and K. Lipartito for his comments. Thanks also to J. Beckert, E. Berrutti, L. Bibard, D. Brady, B. Buchanan, J. Davis, M.-L. Djelic, R. Durand, C. Fioroni, R. Garvía, O. Godechot, C. Hann, R. Heiskala, S. Hitlin, G. Jackson, D. Jenkins, P. Kremp, J. Kurczewski, J. Lazarus, S. Lukes, D. Mayrl, C. McWatters, K. Miller, W. Norman, J. Olick, Á. Recoba, M. Savage, J.-C. Spender, I. Tavory, B. Thatcher, S. Vitols, L. Yalçin-Heckmann, S. Weber, C. Zaloom, and V. Zelizer. Audiences at the London School of Economics, Northwestern University, University of Iowa, University of Tampere, University of Warsaw, Telfer School of Management, Stern School of Business, Institute for Advanced Studies in Culture, Kenan Institute for Ethics, MaxPo, HEC, ESSEC, Universidad Carlos III, Wissenschaftszentrum Berlin, and Max-Planck-Institut für ethnologische Forschung provided valuable feedback. K. Kimura at the University of Chicago's Special Collections, and C. Brewer, J. Bunde, and E. Chapin at New York University Archives provided valuable assistance. The NYU Department of Sociology and the Lichtenberg-Kolleg at GeorgAugust-Universität Göttingen provided valuable support.

I use footnotes for primary sources, but parentheses for secondary sources. Per the usual convention, the acronym "CSR" stands for corporate social responsibility. Responsibility for any errors, nonsense, and gobbledygook isn't social, let alone corporate, but my own.

** Prof. Dr. Gabriel Abend, Department of Sociology/New York University, 295 Lafayette Street, US-10012 New York, E-Mail: abend(at)nyu.edu. 
schehens, das unser Verständnis von Gesellschaft, Moral und den moralischen Grundlagen kapitalistischer Gesellschaften am besten ausleuchtet. Anschließend gehe ich auf eine Facette des moralischen Hintergrunds ein, die für das wissenschaftliche Verständnis von Unternehmensetbik und CSR besonders interessant sein könnte: Die Abgrenzung von Moral. Wie werden Grenzen zwischen moralischen und nicht-moralischen Dingen gezogen? Wie werden sie institutionalisiert und kontrolliert? Wie variieren sie über Zeit und Raum? Und ich zeige auch, warum diese empirischen Fragen konzeptuell kniffeliger sind als es auf den ersten Blick erscheinen mag.

Schlagwörter: Unternehmensethik, CSR, Moralischer Hintergrund, Abgrenzung, Geschichte

(I)n the last ten, or shall I say, the last five years, business men have come into a new view of business itself. We used to hear the question frequently asked, 'Have I not a right to do what I will with mine own?' This question is now answered universally: 'No! Not so.' (...) The leaders of business recognize today that their possessions are the result of social influence and that the duty of service to their fellowmen as broad as possible faces them. (Charles W. Eliot, 1909¹)

Business ethics is one of those fundamentals (fundamental aspects of all business) which has been, if not neglected, at any rate inadequately treated. (Edwin F. Gay, $\left.1924^{2}\right)$

There was a time when the sole responsibility of the businessman was considered to be... to make money. (...) But that idea has long since vanished, and one much more appropriate to the complicated and challenging world of 1948 has taken its place. This new concept is, of course, that the businessman's responsibilities extend far beyond himself and his immediate associates; that the chief ones, in fact, are to others, to the many groups on which his decisions and actions have some sort of impact. (...) If he refuses to accept these responsibilities, then they certainly will be taken over by someone else-by someone antagonistic to business management and to free enterprise, the only system under which business management can operate. (Harwood F. Merrill, 1948 ${ }^{3}$ )

\section{I}

At the normative, first-order level, the history of business ethics and CSR in the United States is largely monotonous. Instead, I argue for a historical approach that focuses on the moral background or second-order level. The moral background is where the action is - at least, the action that sheds most light on our understanding of society, morality, and the moral foundations of capitalist societies.

1 "Is not Materialistic." The Washington Post Dec 30, 1909, p. 11. Charles W. Eliot was Harvard University's president from 1869 to 1909 . He delivered this address at the Southern Educational Conference in 1909.

2 Gay, E. F. (1925). "Courses in Business Ethics in Our Schools of Business Administration." Proceedings of the Sixtieth Convocation of the University of the State of New York. University of the State of New York Bulletin No. 824: 96-98. Edwin F. Gay was the first dean of Harvard's business school from 1908 to 1919. He delivered this address at the University of the State of New York in 1924.

3 Merrill, H. F., ed. (1948). The Responsibilities of Business Leadership. Cambridge: Harvard University Press, p. vi. 


\section{II}

The history of business ethics and CSR encompasses three interconnected yet distinct aspects (Abend 2013: 173). First, there is the history of business practices with respect to their ethics or morality - for example, variation across time and place in the incidence of fraud, bribery, or false advertising, or variation across time and place in companies' environmental policies or exploitation of workers. Second, there is the history of ideas about business ethics and CSR - including both (a) the more highbrow ideas of philosophers, theologians, jurists, and organization theorists, and (b) the more practical or applied ideas of managers, policymakers, legislators, journalists, preachers, and educators. Third, there is the history of projects and institutions intended to have an effect on business practices with respect to their ethics and CSR - including legal and organizational devices, the work of educational organizations, religious organizations, business associations, the media, codes of ethics, awards, groups, meetings, videos, and public statements and lectures.

A comprehensive historical account should investigate these three aspects, their interconnections, and their embeddedness in social and political institutions. Naturally, this article is narrower: it concentrates on one aspect of the third aspect. The key actors in my story can be called business ethicists, even if they have full-time jobs as storekeepers, bankers, legislators, journalists, or priests. Equally key are certain organizations that sometimes partake in the business ethics business - business associations, business schools, state agencies, special commissions, political organizations, civil society organizations, religious organizations and groups, business ethics associations, or ethics and compliance officers associations.

Crucially, I look at business ethics from the perspective of "public moral normativity" (Abend 2014: 21f.). I have nothing to say about organizations' backstage, private deliberations, and goals (e.g., their true priorities, as decided behind closed doors). Nor do I have anything to say about individuals' mental states (e.g., someone's true beliefs, motives, intentions, or desires). For the most part, my arguments are based on public evidence. This evidence is about business ethics institutions and projects whose aims are normative. They concern themselves with what ought to be the case and what ought to be done. They spell out what morally good businesspeople are expected or supposed to do, be, and believe. They exhibit business ethics ideals and models: what an exemplary businessperson, firm, or course of action looks like. They try to persuade, prescribe, encourage, urge, motivate, and bring about action.

Unlike nonhuman animals' groups, human societies are rife with normativity; "ought" is central in daily life as much as in formal organizations and the law (cf. Darwin 1872: 67). Unlike psychological facts, social facts are in principle observable, external to individuals, and in a significant sense independent of them (cf. Durkheim 1982; Goffman 1959; Lukes 2006). Thus, my historical data are orthogonal to issues such as the truthfulness of businesspeople, business ethicists, or politicians. Suppose a CEO publicly affirms that her decisions are always consistent with the highest ethical and CSR standards. I can't help elucidate whether she truly meant what she said, or this is her firm's calculated strategy, driven by marketing and public relations considerations. Rather, I'm interested in public moral normativity for its own sake. 
The historical data displayed in this article are meant to be illustrative; they were selected to illustrate patterns to which my book, The Moral Background, gives more systematic support. Unfortunately, the strengths and weaknesses of my methodological approach, sample, data collection, and data analysis can't be discussed here. Finally, my investigation is about the history of business ethics and CSR in the United States. I don't know if my claims hold water elsewhere.

\section{III}

In May 1924 the Chamber of Commerce of the United States held its twelfth annual meeting in Cleveland. The last day of the meeting it approved the "Principles of Business Conduct": 15 principles that business associations and businesspeople were urged to follow. ${ }^{4}$ Because of their originating in an influential organization led by influential individuals, they would appear in numerous publications and be widely discussed and commended. They were also adopted by numerous associations, and were printed as a separate sheet for distribution, a large number of which were reportedly distributed. ${ }^{5}$

What did these Principles of Business Conduct advocate? Consider these examples:

"I. The foundation of business is confidence, which springs from integrity, fair dealing, efficient service, and mutual benefit.

III. Equitable consideration is due in business alike to capital, management, employees, and the public.

VI. Obligations to itself and society prompt business unceasingly to strive toward continuity of operation, bettering conditions of employment, and increasing the efficiency and the opportunities of individual employees.

VIII. Representation of goods and services should be truthfully made and scrupulously fulfilled.

IX. Waste in any form, of capital, labor, services, materials, or natural resources, is intolerable and constant effort will be made toward its elimination.

$\mathrm{X}$. Excesses of every nature, inflation of credit, over-expansion, over-buying, overstimulation of sales, which create artificial conditions and produce crises and depressions are condemned.

XI. Unfair competition, embracing all acts characterized by bad faith, deception, fraud, or oppression, including commercial bribery, is wasteful, despicable, and a public wrong (...).

XIII. Corporate forms do not absolve from or alter the moral obligations of individuals $(\ldots) . "{ }^{6}$

Among other things, then, this code of ethics highlighted some of the usual suspects: competition shouldn't be unfair, business has obligations to society, and business has

\footnotetext{
$4 \quad$ "Will Government Be Kept Out of Business?" Outlook May 21, 1924, p. 86.

$5 \quad$ "News of Organized Business." Nation's Business May 1928, p. 170.

$6 \quad$ Nation's Business Sep 1924, p. 66.
} 
obligations to the environment (here "waste" and "conservation" were usual keywords). ${ }^{7}$ These were common issues in the first decades of the twentieth century, and so was the code of ethics as a genre and tool. Another common issue at the time was executive overcompensation.

For instance, in 1905 the Boston magazine The Arena censured executives' "handsome private-car(s)," "the lavish waste of the policy-holders' money," and "the reign of extravagance, loot and waste that is one conspicuous feature of the management of the big New York companies." An insurance company executive's

"salary was thirty thousand dollars; he wanted it raised, so forthwith he received seventy-five thousand dollars. This, however, did not satisfy his growing appetite, and ere long we find it raised to one hundred thousand, or double that received by the President of the United States (...). In five years (...) the salaries of the Equitable Assurance Society's officials jumped from the extravagant figure of $\$ 380,100$ per annum to the enormous figure of $\$ 613,300$ (...). All these are merely typical illustrations of the reign of extravagance, loot and waste that is one conspicuous feature of the management of the big New York companies."

What's more, The Arena continued, the "corruptionists of Wall street" were "gambling with trust-funds," "speculating or gambling with watered stocks," and "defrauding the millions and placing their earnings in jeopardy." 8 Such ethical concerns were to be expected from The Arena, a Progressive Era magazine, founded in 1889 by Benjamin Orange Flower. It has been described as "the most influential of all radical journals," even though Flower - the "father of the muckrakers" (Fairfield 1950)—wasn't a socialist. "What was wrong with America, so far as he could see, was the degeneration of character: too much wealth had brought about greed and inequality" (Filler 1993: 40). ${ }^{9}$

No doubt, Wall Street also had many defenders, whose moves reveal what and whom they were defending it from. Take Henry Clews-described at the time of his death in 1923 as "'the dean of Wall street,' author and public speaker, for more than 50 years (...) one of the leading financiers in the United States." 10 The historian of business

$7 \quad$ The "National Conservation Commission" was established in 1908 and the "National Conservation Exposition" took place in 1913. See also Chase's books The Challenge of Waste (1922) and The Tragedy of $W$ aste (1925) — where a relatively rapid transition from challenge to tragedy seems to have occurred; and Lowry, R. J. (1913). "The Cry of Conservation." Atlanta Constitution Jul 27, p. B5. Cf. Cumbler (2000); Hays (1959); Rosen (1995).

$8 \quad$ "Great Insurance Companies as Fountain-Heads of Political and Commercial Corruption." The Arena Vol. XXXIV, No. 192, Nov 1905, pp. 514-523. Quotation is at pp. 516 and 523. On executive compensation, see Frydman/Saks (2010); Frydman/Molloy (2012); Wells (2010). See also Taussig, F. W., and Barker, W. S. (1925). "American Corporations and Their Executives: A Statistical Inquiry." Quarterly Journal of Economics 40 (1): 1-51.

$9 \quad$ See, e.g., Blankenburg, R. (1905). "Forty Years in the Wilderness; or, Masters and Rulers of "The Freemen' of Pennsylvania." The Arena Vol. XXXIII, No. 182, Jan 1905, pp. 1-10; “The MuckRake versus the Muck." The Arena Vol. XXXV, No. 199, Jul 1906, p. 623; Vrooman, H. (1894). "The Organization of Moral Forces." The Arena Vol. IX, No. 3, Feb 1894, p. 348.

$10 \quad$ "Death Calls Noted Banker." Los Angeles Times Feb 1, 1923, p. 14; "Henry Clews, Dean of Wall St., Dead." Washington Post Feb 1, 1923, p. 2; see also "Henry Clews, Banker, Dies In 83d year." New-York Tribune Feb 1, 1923, p. 1. 
ethics and the historian of finance have much to learn from Clews' speeches and writings, not because he was an impartial observer, but because of the specific ways in which he was partial—see, e.g., "Delusions about Wall Street" (1887), The W all Street Point of View (1900), his Louisville address "The Situation" (1907), and Fifty Years in Wall Street (1908). ${ }^{11}$

For example, in "Wall Street as It Really Is. A Vindication" and "The Ethics of Wall Street," Clews asserted that "there is no more honorable and responsible body of men in the world than its bankers and the members of the New York Stock Exchange." Regrettably, people misjudged it:

"There is probably no great institution in the world that is so persistently misrepresented and so generally misunderstood as that which is known as Wall street. Even among otherwise intelligent men it seems to be the impression that the street is nothing more nor less than an unchartered association of bandits and robbers masquerading under the names of bankers, brokers and operators who are banded together in an unholy conspiracy to wreck railroads, 'freeze out' stockholders and to first 'pull the wool' over the eyes and then from off the backs of any unwary 'lambs' that wander innocently into their haunts." 12

What to make of the preceding three historical vignettes-the Principles of Business Conduct (1924); The Arena's denunciation of "Great Insurance Companies as FountainHeads of Political and Commercial Corruption" (1905); and Henry Clew's apologias for Wall Street (1890 and 1908)? These are heterogeneous data points, and more social, economic, and cultural context would be needed to fully understand them. Still, they can help me pose a simple question. Don't these vignettes ring familiar, even to someone unfamiliar with U.S. business and political history? Indeed, don't they ring strikingly contemporary?

I argue that the history of business ethics and CSR is in certain regards a monotonous and predictable affair. This claim is developed in sections IV to VI. Sections VII to XII present my moral background approach, with special emphasis on the demarcation of morality as an empirical question.

\section{IV}

These days it's often heard that contemporary business ethics and CSR are more complex than ever before. It's often heard that the business world used to be simpler and

\footnotetext{
11 Clews, H. (1887). "Delusions about Wall Street." The North American Review 145 (371): 410-421.

12 Clews, H. (1890). "The Ethics of Wall Street." Cosmopolitan 9 (5): 596-601. Quotation is at p. 596. Similarly, Clews (1908) wrote in "Wall Street as It Really Is. A Vindication" (chapter LXXXIII in Fifty Years in W all Street): "Many people, and some newspapers, have a false impression that Wall Street is a gambling arena that does a great deal of harm and no good, and that it ought be, as far as possible, abolished... But those who know Wall Street well have no such impressions of it (...). They can, on the contrary, testify that there is no more honorable and responsible body of men in the world than its bankers and the members of the New York Stock Exchange, and that nowhere is honesty, integrity, and good faith more resolutely exacted than on the Exchange (...); and nowhere is a black sheep, when discovered, more quickly and several punished than there." Clews, H. (1908). Fifty Years in Wall Street. Irving Publishing Company, p. 955.
} 
slower, and hence business ethics and CSR were simpler and slower as well. If illustrations are called for, a comparison might be drawn between the ethical issues that could arise in a general store in the eighteenth century, a factory in the late nineteenth century, and a multinational corporation in the early twenty-first century.

This oft-heard view might be in some ways right. However, there are some other ways in which things haven't changed very much. One is the typical modern cliché that things are now more complex and faster than ever before. In the past "business life moved more slowly than it does in these flush times"; today, business is "conducted with (...) astonishing rapidity," and all that is solid melts into air. ${ }^{13}$ Another is the normative content of business ethics institutions, understandings, and projects. I have analyzed the work of hundreds of business ethicists and organizations throughout U.S. history, from colonial times to the present (only some of which are reported in The Moral Background). They have hoped, through various means, to persuade businesspeople and future businesspeople to follow moral principles and prescriptions. They can be found at work in diverse loci and sources: business ethics books and pamphlets, newspaper editorials and articles, legislative debates, investigative committees, series of lectures and sermons, awards, university classes, public speeches, court cases, annual reports, codes of ethics, or business associations' records.

What long-term normative picture emerges from these data? Business ethicists always insist that businesspeople shouldn't cheat, lie, deceive, etc., and that companies have obligations beyond profit-making. A businessperson "ought to be honest and truthful, act with integrity, care about his community, not shortchange his customer, not misrepresent his products, not mistreat his employee, and not falsify his books. (...) True, there are differences regarding terminology, sophistication, the types of firms considered, what practices are actually deemed permissible and impermissible, how to implement and enforce principles, and so on. Still, the normative bottom line has been remarkably stable. The overall picture is one of normative continuities and consensus, and only sporadic, minor differences and outliers" (Abend 2014: 20).

In this sense, despite the enormously divergent contexts, today's business ethics and CSR manuals are still reminiscent of Richard Steele's 1684 business ethics manual, The Trades-man's Calling. They are reminiscent of Steele's manual, despite Steele's being a seventeenth-century nonconformist minister, whose basic premises were God, Mammon, and Sin, and whose aim was "to guide the honest-minded Tradesman in the right way to Heaven." 14 In turn, Steele was building on centuries of Christian thought about

13 Alger, G. W. (1904). "Moral Overstrain." Atlantic Monthly 93: 496-500. Quotation is at pp. 499f.; Alger, G. W. (1906). Moral Overstrain. Boston and New York: Houghton Mifflin, p. 17. "All that is solid melts into air" is one translation of Marx and Engels's "alles Ständische und Stehende verdampft." Cf. Berman (1982); Rosa (2005).

14 Richard Steele's (1629-1692) manual, The Trades-man's Calling, was first published in London in 1684; a second edition appeared in 1698. But only long after Steele's death a revised version achieved great success, now under a new title, The Religious Tradesman; Or, Plain and Serious Hints of Advice for the Tradesman's Prudent and Pious Conduct, and with a "recommendatory preface" by Isaac Watts (dated 1747). This version was published in Newburyport, Massachusetts (178-?), London (1792), Charlestown, Massachusetts (1804), Philadelphia (1807), Trenton, New Jersey (1823), among other places. 
what's right and wrong in commerce, and what a pious merchant should and shouldn't do. These problems had been tackled by important theologians, jurists, and the law (cf., e.g., Reyerson 1982) — to mention but one important example, Aquinas devotes a question in the Summa Theologiae to "fraud committed in the course of buying and selling." 15 Not surprisingly, the ultimate source for this body of business ethics was the Christian scriptures, e.g., commendations of commercial honesty and condemnations of false weights and measures. ${ }^{16}$

At any rate, there is nothing specifically Christian about worries about commercial honesty. Commerce necessitates some degree of trust and hence some degree of ethical behavior; demands for it and complaints that there isn't enough of it are historically frequent. Equally historically frequent is the idea that business ethics and CSR "make bottom-line sense," there is a "business case" for them, and many other variants of "doing well by doing good" and enlightened self-interest (including "honesty is the best policy"—-see, e.g., Needham's Honesty's best policy (1678); Plain dealing is a jewel, and honesty the best policy (1682); or Lawton's Honesty is the best policy (1689)).

Moreover, as Herbert Spencer observed in the 1850s, here size doesn't matter:

\begin{abstract}
"It is not true, as many suppose, that only the lower classes of the commercial world are guilty of fraudulent dealings: those above them are to a great ex- tent blameworthy. On the average, men who deal in bales and tons differ but little in morality from men who deal in yards and pounds. Illicit practices, of every form and shade, from venial deception up to all but direct theft, may be brought home to the higher grades of our commercial world. Tricks innumerable, lies acted or uttered, elaborately-devised frauds, are prevalent—many of them established as 'customs of trade;' nay, not only established but defended."
\end{abstract}

Thus, big business, the "higher grades of the commercial world," shows the "same lack of conscientiousness which shows itself in the mixing of starch with cocoa, in the dilution of butter with lard, in the colouring of confectionary with chromate of lead and arsenite of copper." Except that it "must of course come out in more concealed forms; and these are nearly, if not quite, as numerous and as mischievous." 17

Today, concerns about business honesty and business ethics are still prominent in public life. Twenty-first century societies wonder why they might be lacking, and how they might be fostered, incentivized, nudged, and enforced. However organizationally or culturally complex such issues might have become, their normative essence is already manifest in Aquinas, Cotton Mather, or Joshua Bates. ${ }^{18}$

\footnotetext{
15 Summa Theologiae 2a2ae, 77.

16 E.g., Leviticus 19: 35-36: Deuteronomy 25: 13-16; Proverbs 11: 1; Proverbs 16: 11; Proverbs 20: 10; Proverbs 20: 23; Hosea 12: 7; Amos 8: 5; Micah 6: 10-11; Romans 12: 17; 2; Corinthians 8: $20-21$.

17 Spencer, H. (1859/1888). “The Morals of Trade." Pp. 107-48 in Essays: Moral, Political and Aesthetic. New and enlarged edition. New York: D. Appleton and Company, pp. $107 \mathrm{f}$.

18 Bates, J. (1818). A Discourse on Honesty in Dealing. Middlebury, VT: J. W. Copeland; Bellows, H. W. (1848). The Christian Merchant: A Discourse Delivered in the Church of the Divine Unity, on Occasion of the Death of Jonathan Goodhue. New York: C. S. Francis \& Co.; Mather, C. (1705). Lex Mercatoria: Or, the Just Rules of Commerce Declared. Boston: Printed and sold by
} 
In the first decade of the twenty-first century, in the wake of several scandals and crises, U.S. pundits and journalists helped themselves liberally to superlatives and expressions like "never before," "unheard of," "unprecedented," and "new." Yet, pundits and journalists are rarely good historians. Nor do they have the time to study the genealogies of the present-day affairs they are hired to talk about-especially if their employers only care about "hits" or "clicks" (Petre 2015). In fact, far from being unprecedented, recent events are so eerily reminiscent of past events that it feels as though history were cyclical.

One common narrative is as follows. In the wake of a scandal or crisis, its moral causes are publicly identified and decried. Activists, politicians, intellectuals, journalists, muckrakers, and civil society organizations produce jeremiads about the ethics of business today-no matter what day the indexical word "today" refers to. Government, business associations, "business leaders," and business schools are criticized for failing to prevent what happened, and are urged to urgently do something going forward. Social movement activity and moral indignation grow. People grow wary of big business and "the one percent." Prescriptions proliferate as to what business, businesspeople, and government should and shouldn't do now. In response to these criticisms, powerful economic and political actors concede that there might be some merit to them, but deny that there's any need for structural or systemic change. Capitalism is not only compatible with morality, but it actually promotes essential moral virtues. An official commission might be set up to investigate and make practical recommendations. ${ }^{19} \mathrm{New}$ laws might be passed. ${ }^{20} \mathrm{~A}$ few blameworthy individuals might end up in prison.

Soon one sees more university courses and lectures on business ethics; endowed chairs and institutes; grants and fellowships; conferences; reports on how to improve ethics education; textbooks, cases, and bibliographies ${ }^{21}$; and universities' "renewing and reinvigorating their commitment to ethics in business education." 22 Skeptics object that these

Timothy Green; Mather, C. (1710). Theopolis Americana: An Essay on the Golden Street of the Holy City. Boston: Printed by B. Green.

19 E.g., Investigation into the Causes of the Gold Panic. Report of the Majority of the Committee on Banking and Currency (1870); Armstrong Committee report, Testimony Taken Before the Joint Committee of the Senate and Assembly of the State of New York to Investigate and Examine into the Business and Affairs of Life Insurance Companies Doing Business in the State of New York (1905-1906); Report of Governor Hughes' Committee on Speculation in Securities and Commodities (1909); Pujo Committee report, Report of the Committee Appointed Pursuant to House Resolutions 429 and 504 to Investigate the Concentration of Control of Money and Credit (1913); or The Financial Crisis Inquiry Report. Final Report of the National Commission on the Causes of the Financial and Economic Crisis in the United States (2011).

20 E.g., Pure Food and Drug Act (1906), Sherman Act (1890), Elkins Act (1903), Hepburn Act (1906), Federal Trade Commission Act (1914), or Sarbanes-Oxley Act (2002).

21 Edwards, R. H. (1910). Business Morals. N.p.; Hood, E. W. (1930). An Introduction to the Study of Business Ethics. New York: R. W. Bryant; Lord, E. W. 1926. The Fundamentals of Business Ethics. New York: The Ronald Press Company.

22 Berg, E. N. (1988). "Harvard Will Require M.B.A. Ethics Course.” New York Times Jul 13, 1988, p. D2; Ethics Education in Business Schools. 2004. Tampa: AACSB, p. 14; Fowler, E. M. (1987). “Industry's New Focus on Ethics." New York Times Aug 11, 1987, p. D21; Norman (2004); Piper et al. (1993); Salmans, S. (1987). "Suddenly, Business Schools Tackle Ethics." New York Times Aug 2, 1987, p. EDUC64; Shaping Tomorrow's Business Leaders: Principles and Practices for a Model Business Ethics 
efforts are pointless, since ethics can't be taught. Someone might add, be it in 2015 or 1910 , that "the formality and artificiality of a formal course in business ethics would defeat its very purpose." 23 To which someone replies: that's not so!

Soon one sees more ethical codes; ethics and compliance officers; eulogies and panegyrics of unimpeachable businesspeople; CSR reports and statements; brochures; trade books; magazine articles; business ethics awards; and committees on business ethics (or "business methods"24). Annual reports stress that employees are taught "sound principles of business ethics and practices," and "the Company has made special endeavors to live up to the highest ideals of modern business ethics." 25 Skeptics object that none of this influences actual business practice, or worse, they are but marketing ploys and "window dressing" (Krum/Greenhill 1972: 388). Someone might add, be it in 2015 or 1920, that ethical codes are "high-sounding and pleasantly worded," whereas "the actual world of business experience is plainly a cutthroat, 'dog-eat-dog' proposition"; indeed, "many such a code is a hypocritical camouflage or a stupid smoke-screen, including (...) 'smug preambles,' 'pious protestations,' and 'artful gestures'." 26 To which someone replies: that's not so!

Eventually, the whole affair loses steam and fades from center stage. Eventually, a new scandal or crisis sparks a new cycle.

While Wall Street and financial companies aren't always the key actors in this narrative, sometimes they do play a key role. In such cases, critics denounce "(manipulations) by the votaries of frenzied finance," 27 deplore that "(g)ambling in stock and futures" is "an evil of national proportions," 28 and depict the New York Stock Exchange as "the lair of the money devil." ${ }^{29}$ Calls to "Occupy Wall Street" might ensue. For instance, just like in 2007-

Program. 2007. Business Roundtable Institute for Corporate Ethics; Swanson/Fisher (2011); Windsor's (2002) “Open Letter on Business School Responsibility”; Windsor (2004). Person, H. S. (1913). “The Amos Tuck School of Dartmouth College." Journal of Political Economy 21 (2): 117-126. Quotation is at p. 126. See also Anteby (2013): 68f.

$24 \quad$ Gundaker, G. (1921). "The Cornerstone of Rotary.” The Rotarian Dec 1921, pp. 321-323; Havens, R. M. (1923). “Business Codes.” The Rotarian Sep 1923, pp. 8f., 34-36; Rotary International (1923). Proceedings. Fourteenth Annual Convention of Rotary International, pp. 181f. Company of America. Annual Report-1912, p. 12.

Taeusch, C. F. (1926). Professional and Business Ethics. New York: Henry Holt and Company, pp. 260 and 264. Cf. "Codes of Ethics." The Independent Dec 13, 1924, p. 503; Brooke, W. G. (1924). "Codes of Ethics for Business and Commercial Organization." International Journal of Ethics 35 (1): 41-59; Heermance, E. L. (1925). "Letters to the Editor. Honor and Brickbats." The Independent Jan 17, 1925, p. 84. See also Boltanski/Chiapello (1999); Shamir (2004; 2010: 539).

27 Lawson, T. W. (1905/1906). Frenzied Finance. London: William Heinemann, p. xi. Edwards, R. H. (1910). Business Morals, p. 15. P. (1914). "Ethics in College: The Relation of College Study of Ethics to the Character of Students." Religious Education Vol. IX, No. 6, pp. 584-588. Quotation is at p. 587. See also Brandeis, L. D. (1913/1914). Other People's Money and How the Bankers Use It. New York: Frederick A. Stokes Company. 
2008, "(o)ne effect of the crisis of 1907 has been to give a new impulse to Wall Street detraction, and sharpen the teeth and claws of the detractors."30 Just like in 2007-2008, "wolves" of Wall Street are condemned and cartoons about the ethics of finance surface:

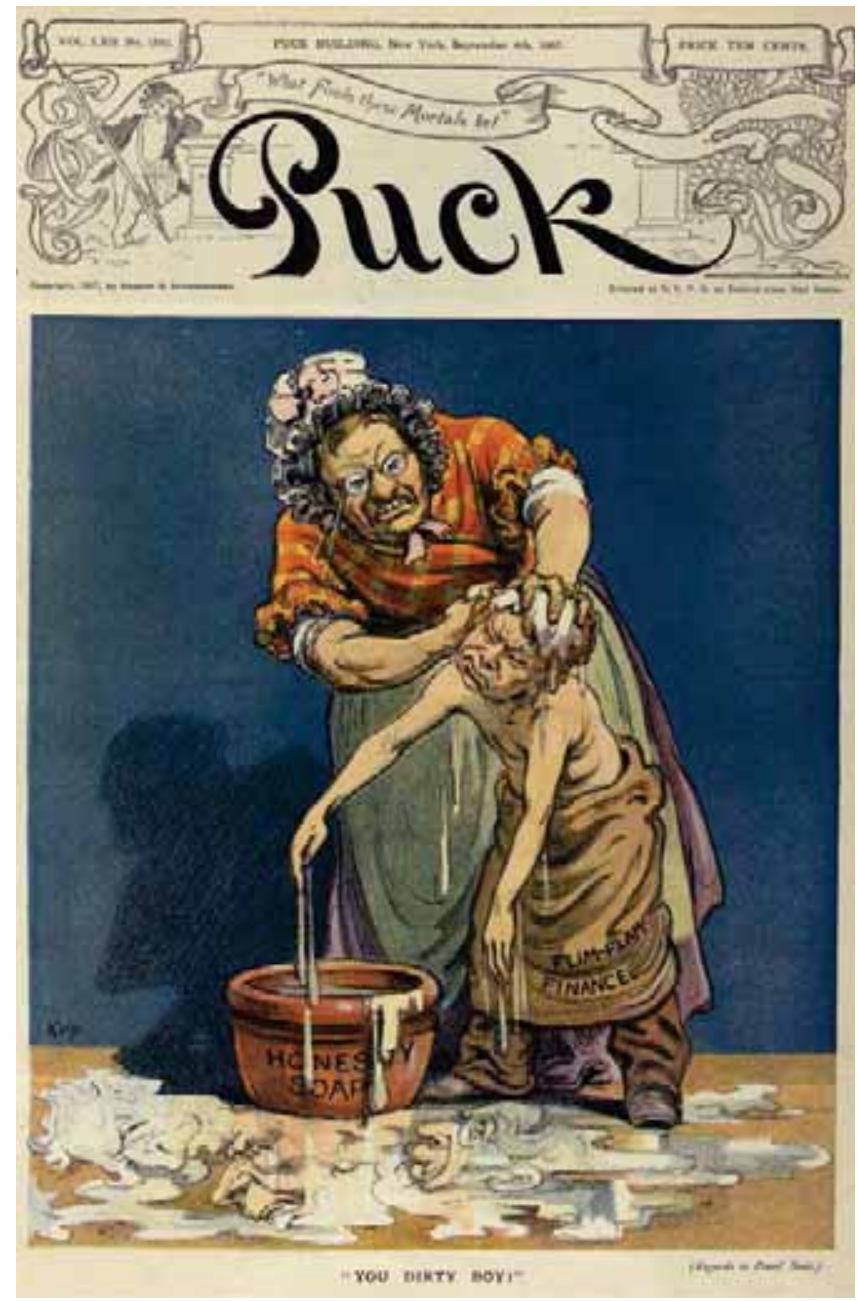

Figure 1: "You dirty boy!" (Source: Puck Vol. LXII, No. 1592, September 4, 1907)

No doubt, these forces generate counterforces. In the wake of scandals and crises, there are also defenders of the ethics of American business in general and Wall Street in particular-who hasten to declare their "absolute faith in the patriotism and public spirit of the Stock Exchange." 31 Logically, representatives of business and finance are quick

\footnotetext{
$30 \quad$ Clews, Fifty Years, op. cit., p. 962.

31 Morgan, J.P. (1912). J. P. Morgan's Testimony. The Justification of W all Street. This is J. P. Morgan's testimony before the Pujo Committee on December 18 and 19, 1912. Cf. Carroll et al. (2012): 103f.; Cowing (1965); Geisst (2004): 129-132.
} 
to try to defend themselves; sympathetic politicians are quick to follow suit. Their characteristic moves have always been pretty much the same, too, whether in the early twenty-first or in the early nineteenth centuries. One of them is the a-few-bad-apples argument, also known as the a-few-black-sheep argument. ${ }^{32}$ It goes like this: American business is overall in good ethical shape, but, alas, there are still a few exceptions. These unethical people are "despised parasites, for whose extermination the men who do the real business in the 'street' never cease to work." 33 Thus the problem isn't structural; getting rid of these anomalies will solve it.

For most commentators, "a few bad apples" has meant very few bad apples. For a few commentators, "a few" has meant as much as ten percent. As William E. Humphrey, chair of the Federal Trade Commission (1925-1933), maintained: "I do not believe that business is generally crooked. (...). I do believe that 90 per cent of American business is honest. I believe that 90 per cent of American business is anxious to obey the law. I want to help this 90 per cent of honesty. I want to control or destroy the 10 per cent that is crooked." 34 Either way, whatever the estimate of the present ratio of bad to good apples, this argument is habitually accompanied by optimistic predictions: most of the bad apples have now been found out, things are already getting better (or will soon start to get better), future enforcement will be more effective, and so on. For example, in September 1907 the abovementioned Henry Clews gave a speech in Louisville, Kentucky, where he discussed "the corporations known to have been among the most flagrant violators of the anti-rebate law":

"These violators were not the corporations, which we all know have no souls, but their officers, yet the officers have gone thus far unwhipped of justice, much to the disgust of the masses of the people. But in the future this defect should be remedied and rich and poor among the individual violators of the law should be prosecuted criminally, and upon conviction sent to jail like any other criminals. (...). (These men) showed a moral laxity which has been exposed and branded as a crime, and instead of it let us hope they have now a sense of corporate responsibility and honesty (...). They will certainly find that honesty is the best policy." 35

32 Anderson, F. B. (1911). Morals in Trade and Commerce, pp. 6-8; Clews, Fifty Years, p. 955. See also Ott $(2009 ; 2011)$.

33 Johnson, J. F. (1917). Business and the Man. New York: Alexander Hamilton Institute, p. 126.

34

"Integrity of Business Is Creed of Humphrey." Nation's Business Apr 1928, p. 138.

Clews, H. (1907). The Situation. An Address by Henry Clews, LL. D. Delivered at the Fifteenth Annual Convention of the Kentucky Bankers Association, p. 10. See also Clews's "Financial and Trade Situation and Prospects," an address at the Annual Banquet of the National Association of Cotton Manufacturers on April 16, 1908 (chapter LXXXVI in Fifty Years in Wall Street): "Corrupt, plundering, and law-breaking officers of banks, and railway, insurance, and other large corporations have, in many cases, been exposed and shown the error of their ways, and we have in consequence a higher business morality than we had before we passed through this ordeal of purification. (...). Banks and trust companies and railways, insurance, and other corporations have been freed from much unsound and dishonest management, and also loose, grafting and speculative practices, and we have in their place that higher moral tone which is safeguarded by greater publicity of accounts and more rigid official examinations under new and stricter laws than ever before." Clews, Fifty Years, p. 1031. 
Clews wasn't a seer (as far as I'm aware), so he couldn't foresee the events that would transpire the following month-the "Panic of 1907" or "Knickerbocker Crisis." More important, his view about the long term is dubious: historical experience shows such optimism to be unwarranted. "Moral laxity," lack of "corporate responsibility," and dishonesty haven't gone away. The purportedly "old days of harshness and indifference to employees, contempt for the law, and exploitation of the public" never seem to grow old. ${ }^{36}$ Many subsequent observers, many subsequent Henry Clews, would be equally optimistic and equally mistaken. More generally, the whole pattern repeats itself every time a big corporate scandal or financial crisis comes about.

\section{VI}

In the aftermath of World War II, many questions were raised in the United States about the social responsibilities of business. A good illustration is The Responsibilities of Business Leadership (1948), edited by Harwood Merrill. ${ }^{37}$ Another good illustration is Social Responsibilities of the Businessman (1953), by Howard Bowen-whom "(a) wide consensus among students of social responsibility history celebrates... as the founding father of the CSR concept" (Acquier et al. 2011: 608). However, wide consensuses don't always get it right. Years before Bowen and Merrill, many questions had already been raised in the United States about the social responsibilities of business: what its duties were, to whom they were owed, under what conditions it had them, why it had them, and how they ought to be "discharged." 38 These issues were often addressed by the business press, business associations, business schools, and Progressive businesspeople, journalists, and reformers-particularly because the large corporation or "big business" seemed to have special duties, and then wartime seemed to entail special duties, too. They were also addressed by politicians and state agencies that wished to foster "cooperation" and certain corporatist policies, and thereby mitigate capitalist systems' standard anxieties: destructive competition and labor unrest.

In 1934 "Secretary (of Commerce Daniel C.) Roper... went to New York to talk to the League for Political Education about the Social Responsibilities of Business." Roper rehearsed a common point, which business ethicists repeatedly brought up: "Good business (...) recognizes that it is no longer justifiable (...) to seek money profits alone"; instead, "it must make a definite and equitable contribution to the society upon which it must depend for an existence." ${ }^{39}$ Business depends on society; business draws its

Markham, G. D. (1914). Business and Idealism. St. Louis: Nixon-Jones Printing Co., p. 8.

This volume consists of speeches delivered at the Eighteenth Annual Conference of the Harvard Business School Alumni Association, which took place on June 12, 1948. There was no shortage of high-status speakers that day: "Businessmen's Responsibilities to the Public," by Clarence Francis; "Businessmen's Responsibilities to Employees," by Richard Deupree; "Businessmen's Responsibilities to Government," by Ralph Flanders; "Businessmen's Responsibilities to Consumers," by Jack Straus; “Businessmen's Responsibilities to Stockholders,” by Harry Bullis; and "Businessmen's Responsibilities to the World," by Allen Dulles.

On the history of CSR, see Avi-Yonah (2005); Carroll (1999; 2008); Carroll et al. (2012); Hoffman (2007); Heald (1957; 1961; 1988); Husted (2015); Jones (2013); Kaplan (2015); Marens (2008; 2013); Wells (2002-2003).

"Charting the Course of Business." Nation's Business Apr 1934, p. 27. 
wealth from society; therefore, business has obligations to society. Or, as others preferred to put it, business has obligations to "the community." For instance, in 1928 Thomas R. Preston, President of the American Bankers' Association, spoke about the "profession of banking," and highlighted its "spirit of social responsibility": "The modern banker recognizes it is not sufficient that he merely be shrewd and make a success for himself. (...). He knows that it is above all his place to strive also to be a real public servant and make his community successful." 40

Besides society and the community, business was said to have other obligations: "men of business" had "responsibility in respect to governments, churches, and benevolent institutions"; "to themselves, to society, and especially to their employees"; and to "their homes." 41 In the case of investment banking, its "tripartite nature" meant, first, "obligation to the investing public"; second, "moral responsibility to the business or the government, or political subdivision thereof, for which the investment banker underwrites"; and third "the relation between investment houses which... are competitors with one another." 42 Likewise, according to Haley Fiske, President of the Metropolitan Life Insurance Company, the responsibilities of business could be seen as threefold: relations of businessmen to businessmen ("summed up in one word-cooperation"), "(r)elations to the public," and "(r)elations to employes (sic)." 43

All of these responsibilities and obligations were understandably a major preoccupation for the Chamber of Commerce of the United States. The Chamber, established in 1912, aimed to represent the interests and defend the good name of "American Business." In turn, this aim involved persuading influential social and political actors and public opinion that American business did care about the good of American society. Two presidents' speeches in the late 1920s illustrate the point. William Butterworth, speaking in 1928 about "The Public Responsibilities of Business," stressed that "(b)usiness is the custodian of national prosperity. Problems and practices which affect business welfare thus intimately affect the welfare of the nation and its people. This vests the processes of business with a public interest and entails a distinct public responsibility. This responsibility increases as business horizons widen and as its processes become more intricate and complex and more and more intimately intertwined with the daily life of our people." ${ }^{4}$ Julius Howland Barnes, speaking in 1929 about "Growing Responsibili-

40 Preston, T. R. (1928). "Spirit of Social Responsibility Rules Banking, Says Preston." New York Herald Tribune Sep 30, 1928, p. A12. See also Teare, R. C. (1931). “The Merchant Ethic.” American Bar Association Journal 17 (4): 223-228 and 268-270.

$41 \quad$ Alexander, J. et al. (1857). The Man of Business Considered in His Various Relations. Anson D. F. Randolph.

42 Callaway, T. (1929). Ethical Problems of Investment Banking. N.p., pp. $1 \mathrm{f}$.

43 Fiske, H.. (1927). “The New Responsibilities of Business.” Nation's Business May 20, 1927, p. 15. See also Follett's (1927) “The Meaning of Responsibility in Business Management," and Mosher's (1927) "The Social and Civic Responsibilities of the Profession of Business Management" — both in Metcalf, H. C., ed. 1927. Business Management as a Profession. A. W. Shaw Company.

44 Butterworth, W. (1928). The Public Responsibilities of Business. Washington: Chamber of Commerce of the United States, p. 3. 
ties of Business," stressed that “(o)rganized business today has a larger measure of public confidence than ever before largely as the result of such evidences of a growing confidence in business responsibility." 45

Similarly, consider the "Resolutions adopted by the Sixteenth Annual Meetings of the Chamber of Commerce of the United States" in 1928: "The Chamber of Commerce of the United States declares its confidence in the general integrity and sound ideals of modern business. These are brought into high relief by recent disclosures of individual violation of established business practices. American business is jealous of its good name, insists upon protecting its professional status by the maintenance of the highest standards, and intends scrupulously to discharge its collective responsibilities." Then, under the heading, "Responsibilities of Business," it was noted that "(c)hief among such responsibilities is that of purging business of all those who indulge in commerce and political corruption and, through resort to unclean or unworthy practices, bring business into disrepute and shock the sensibilities of all decent citizens." Further, "stockholders of corporations owe it to themselves, to the Government, and to the profession of business publicly to repudiate those who misrepresent them. Such stockholders cannot accept the profits flowing from corruption and escape the moral stigma which inheres in such profits." 46

Business ethics and CSR were thought to contribute to business associations' efforts to avoid government regulation. As the Chamber's Principles of Business Conduct stated: "Business should render restrictive legislation unnecessary through so conducting itself as to deserve and inspire public confidence." Alfred P. Sloan, of the General Motors "family" (cf. Marchand 1991), evinced comparable reasons: regulation was detrimental to "the American System." In his 1935 "address delivered at the Annual Dinner of the Congress of American Industry in conjunction with the Annual Convention of the National Association of Manufacturers," held at the Commodore Hotel in New York, Sloan said: "I believe that the time has been reached when a much broader responsibility must be assumed," beyond "the mere physical production of goods and services"; "(i)naction will ultimately mean challenging of industry's position." Sloan added that "(industry) must assume the role of an enlightened industrial statesmanship. To the extent that it accepts such broadened responsibilities, to that degree does it assure the maintenance of private enterprise, and with it the exercise of free initiative, as the sole creator, just as it must always be the most efficient creator, of wealth, hence are advanced the causes of human happiness and security (...)".47

Sloan's speaking of "the maintenance of private enterprise" suggests that regulation was the lesser of two evils. Business ethics and CSR were thought to contribute, too, to another salient social and political concern: avoiding not regulation but revolution. Take Wallace B. Donham's view:

"(A revolution) can be avoided only if our business leaders recognize their responsibility and both think and act wisely in carrying it out. No dam-building process Barnes, J. H. (1929). “Growing Responsibilities of Business.” Nation's Business May 25, 2929, p. 15. "Guide-posts of Business." Nation's Business Jun 5, 1928, p. 19.

Sloan, A. P. (1935?). Industry's Responsibilities Broaden. N.p., pp. 3 and 14.
} 
such as that which preceded the French and Russian revolutions will serve to defend the present against the future. Channels and ditches must be dug, to the end that greater happiness and greater security may flourish where social disintegration and economic insecurity now make life an arid desert for vast numbers. (...) The solution, if any is possible in time to save our western civilization, lies in this field of business ethics." 48

Donham held a central position in the business education field: he was the dean of Harvard University's business school from 1919 to 1942. Throughout his career he had much to say about the ethics and responsibilities of business. ${ }^{49}$ In 1928 he instituted a "Professorship of Business Ethics," which philosopher Carl Taeusch was recruited to occupy (Abend 2008a: 208-212; Copeland 1958: 45, 96; Cruikshank 1987: 168f.; Piper et al. 1993: 151-153). In fact, this idea wasn't new. At Harvard, Edwin Gay (the preceding dean) and Arch Shaw had co-taught a course titled "Social Factors in Business Enterprise" in 1915-1916.50 At the University of California, the College of Commerce launched the Barbara Weinstock Lectureship on the Morals of Trade in 1904. The next year New York University offered a "special course of lectures on business ethics" on subjects such as "Morality in Wall Street" and "Commercial Morality: A Study of Certain of the Conditions and Influences by which it is determined." In 1912-1913 it offered "a specific course in Business Ethics" and hired a "Professor of Business Ethics" - the Episcopal minister Lyman P. Powell. ${ }^{51}$ In this NYU class' examinations, "the questions asked of the student" sound quite timely: "What is the fault of the New York Stock Exchange?"; "Has the business man a right to enormous compensation today?"; "Is speculation ever warranted by ethics?" 52

Donham, W. B. (1930). "Business Ethics as a Solution to the Conflict between Business and the Community." Pp. 28-48 in The Ethical Problems of Modern Finance. New York: Ronald Press Company, pp. 33f.

49 Donham, W. B. n.d. "Putting Ethics into Business." Harvard Alumni Bulletin. Harvard Archives. GSBA. Clippings, 1924-29; Donham, W. B. (1922?) "Fitting the College Man into Business." Baker Library Historical Collections. Donham, W. B. Articles and speeches of. Box 1. Folder Donham, W. B., Addresses and Lectures, 1922-1925; Donham, W. B. (1927). "The Social Significance of Business." Harvard Business Review 5 (4): 406-419; Donham, W. B. (1929). "Business Ethics_A General Survey." Harvard Business Review 7 (4): 385-394.

$50 \quad$ However, in 1924 Gay would say: "As things stand today experience seems to indicate that the desirable instruction can not and should not be given by a special course of lectures on business ethics. (...). If it is required to be added to an already heavily burdened curriculum, it tends to be regarded by the students as a task to be performed perfunctorily, or as a mere bit of 'preaching' not vitally related to the technical training." Rather, "effective instruction in business ethics requires that it be woven continuously into the texture of all the teaching of the school." Gay, E. F., op. cit. Quotation is at pp. 97f. See also Cruikshank (1987: 84), Cuff 1996).

51 Bond, J. H. (1915). "The Teaching of Professional Ethics in the Schools of Law, Medicine, Journalism and Commerce in the United States." PhD dissertation, University of Wisconsin, p. 46; "Morality of Wall Street." Wall Street Journal Apr 25, 1905, p. 5; NYU. 1906. Catalogue 19051906. New York University Bulletin 6 (1): 383; NYU. 1912. Annual Reports of New York University for the Year 1911-1912. New York University Bulletin 13 (1): 5; NYU. 1913. Annual Reports of New York University, p. 11; Powell, L. P. (1925). The Human Touch. New York and London: G.P. Putnam's Sons, pp. 53-55. Cf. Abend (2013).

52 "Business Ethics." Wall Street Journal May 24, 1913, p. 1. 
Around the same time, classes about business ethics were taught by James Tufts at the University of Chicago and by Frank Chapman Sharp at the University of Wisconsin. ${ }^{53}$ "(T)he logic of the situation is irresistible," Powell forecasted in 1912: "(w)ithin the next five years every important university in the United States will have established a department of business ethics." 54 Powell's forecast notwithstanding, though, in 1925-1926 only seven universities required a course in "social control, including ethics," out of thirty-eight members of the American Association of Collegiate Schools of Business (AACSB): Boston University, Chicago, North Carolina, Indiana, Northwestern, Kansas, and Stanford. ${ }^{5}$ It's true that "a number of schools" did "develop formal instruction on the ethical aspects of business conduct," which "(varied) from a few lectures to a fully developed course." 56 Yet, just like today, non-required courses could be taken less seriously. Or not seriously at all. ${ }^{57}$

Besides classes and lectures, several high-status business schools and the AACSB conspicuously emphasized the significance of ethics and social responsibility. At Michigan, for example, one "objective (was) to emphasize to the student, and incidentally to the business community at large, the social function of the business administrator." 58 According to a 1920s survey, "Collegiate Education in Business," more than 85 percent of business school deans, faculty, and university presidents said that "introducing persons with a social point of view into business" was one of the "appropriate aims or purposes of collegiate education for business." 59 For some, this was the very point of a business school; their raison d'etre or "justification." 60 This way business schools could "justify themselves as serviceable and necessary parts of our general scheme of public education." ${ }^{11}$ Else, why should business be taught at universities, alongside philosophy, physics, theology, and medicine?

Reed, H. B. (1916). The Morals of Monopoly and Competition. PhD dissertation, University of Chicago, p. iii; Sharp, F. C., and P. G. Fox. (1937). Business Ethics: Studies in Fair Competition. New York: Appleton-Century-Crofts, p. vi; Tufts, J. H. (1917). The Real Business of Living. New York: Henry Holt; Tufts, J. H. (1919). The Ethics of Coöperation. Boston and New York: Houghton Mifflin; University of Chicago. 1909. Annual Register 1908-1909, p. 221. "Teaching Industrial Efficiency at School." California Outlook Oct 4, 1913, p. 8. Heilman, R. E., Kiekhofer, W. H., Ruggles, C. O., Sharfman, I. L. and Marshall, L. C. (1928). "Collegiate Education for Business." Journal of Business of the University of Chicago 1 (1): 1-59. Bossard, J. H. S., and Dewhurst, J. F. (1931). University Education for Business. Philadelphia: University of Pennsylvania Press, p. 410. See also pp. 12-15, 285, 290, and 409.

"One cannot but contemplate albeit with tongue in cheek, the announcement by another collegiate school of business of a course in business ethics but with the statement that no academic credit will be given for it." Bossard, J. H. S. (1931). "University Education for Business-A Survey." Journal of Business of the University of Chicago 4: 64-77. Quotation is at p. 67. Griffin, C. E. (1928). "The Aims of the School of Business Administration." Michigan Alumnus Vol. 35, No. 8, pp. 159-162. Quotation is at p. 161. Heilman, R. E. et al., op. cit., p. 31. The Ethical Problems of Modern Finance. New York: Ronald Press Company, p. 21; Herrick, C. A. (1904). Meaning and Practice of Commercial Education. New York: Macmillan, pp. 64-65.

1 Wooster, H. A. (1919). "University Schools of Business and a New Business Ethics." Journal of Political Economy 27 (1): 47-63. Quotation is at p. 53. 
At the end of the day, if business committed itself to ethics and responsibility, that could help "(save) our western civilization," as Donham put it. It could help "safeguard the future of private business," as Wigginton Creed put it in his 1921 Weinstock Lecture on the Morals of Trade. ${ }^{62}$ It could also contribute to "industrial peace" or "industrial conciliation," that is, appeasing unruly labor organizations. Not even in the United States could capitalism be taken for granted. The idea was that "capitalism (is) doomed if ethics vanish" - much like Merrill's, Bowen's, Donald David's, and Theodore Levitt's idea after the war, and much like Mark Carney's idea in 2014. ${ }^{63}$

Needless to say, the genealogy of CSR is older and has more lineages than the preceding illustrations might suggest. It's related to the genealogies of charity, philanthropy, and stewardship - both its Christian ("those who are intrusted with a considerable portion of this world's goods (should) be faithful stewards of the same in their life time" ${ }^{64}$ ) and its secular versions. It's related to the history of the professionalization of business, since becoming a profession entailed accepting duties to society (Khurana 2007; Spender 2005; 2007). It's related to the history of the corporate form and corporations' legal, cultural, and social status (Avi-Yonah 2005; Goodpaster/Matthews 2003; Lipartito 1995; 2004; Seavoy 1978; 1982). Finally, the genealogy of CSR is related to the genealogies of various kinds of industrial paternalism, welfare capitalism, and corporate liberalism, and the policies of "enlightened businessmen" to improve their workers' and communities' well-being (Jacoby 1998; Kaufman 2008; McQuaid 2003; Tone 1997). The duties and responsibilities of business had various Christian and secular bases, too. Some businesspeople took their responsibilities to follow from their religious convictions, sometimes cashed out in terms of service and the Golden Rule. ${ }^{65}$ Thus, a Christian businessman ought to "serve the age and the community in which he lives"; "he is responsible for the promotion (...) of these great public interests (the public welfare, the public morals)." ${ }^{66}$ But service and the Golden Rule could be secularly cashed out as

Creed, W. E. (1923). Safeguarding the Future of Private Business. Boston and New York: Houghton Mifflin. "Bank of England governor: capitalism doomed if ethics vanish." The Guardian 28 May 2014; Bowen, H. R. (1953). Social Responsibilities of the Businessman. Harper \& Row; David, D. K. (1949). "Business Responsibilities in an Uncertain World." Harvard Business Review Supplement 27 (3): 18; Levitt, T. (1958). “The Dangers of Social Responsibility.” Harvard Business Review, SeptemberOctober 1958: 41-50; Merrill, H. F., ed. (1948). The Responsibilities of Business Leadership. Harvard University Press. Cf. Marens (2008: 62); Spector (2006; 2008; 2015).

64 "The Epistle from the Yearly Meeting held in London by adjournments, from the 19th of the 5th month, to the 28th of the same inclusive, 1841." The Friend Vol. XIV, No. 47, Seventh Day, Eight Month, 21, 1841, pp. 373f. Quotation is at p. 373; Forster, J. (1869). "On Trade and Commerce." Friends' Review Vol. XXII, No. 29, Mar 13, pp. 449f. Quotation is at p. 449.

Dole, C. F. (1895). The Golden Rule in Business. Meadville: Flood and Vincent; "Glorifying God in Business." Hunt's Merchants' Magazine and Commercial Review Vol. XXL, No. III, Sep 1849, pp. 358f.; Nash, A. (1923). The Golden Rule in Business. New York, Chicago, London, and Edinburgh: Fleming H. Revell; Penney, J. C. (1950). Fifty Years with the Golden Rule. New York: Harper \& Brothers; Penney, J. C. (1956). Lines of a Layman. Great Neck: Channel Press.

“The Christian in Business.” Friends' Intelligencer Vol. XLI, No. 24, Seventh Month 26, 1884, pp. 372-374. 
well. Still others underscored duties due to "business honor" or "mercantile honor." 67 And so on.

\section{VII}

Thus far, my account has highlighted normative continuities and stability in the history of business ethics and CSR. My argument is that these durable normative continuities and stability are underlain by moral background discontinuities and variation. The former I call "first-order" stability and the latter I call "second-order" variation. So, what's this conceptual distinction between the first-order level and the second-order or moral background level? What understanding of morality am I relying on?

The first-order level has two components: (a) first-order behavioral level, i.e., moral behavior and practices; and (b) first-order normative level, i.e., ordinary people's moral judgments and beliefs, and societies' and social groups' moral norms and institutions (Abend 2014: 28-70). For example, two societies or social groups — call them Uruguay and Paraguay (any resemblance to reality is purely coincidental) - may differ as to what's generally considered a well-lived life, what parents and children owe to each other, whether affirmative action is permissible, or whether torture is ever obligatory. They may further differ as to what environmental duties corporations have, to what extent the state should provide for poor people and people with disabilities, or whether capitalism is an intrinsically exploitative system. Two persons - call them Babette and Gottlieb (any resemblance to Swiss theater is purely coincidental)—may differ as to whether property is theft, university education should be free, or abortion is ever permissible. All of these differences are normally referred to as "moral," and they belong to the first-order normative level.

Now, these two countries and these two persons might differ in another kind of way: at the moral background or second-order level. Uruguayans and Paraguayans may not conceptualize exploitation, tolerance, discrimination, moderation, suffering, misery, honor, dignity, or integrity in the same fashion. Or perhaps they don't measure and represent them in the same fashion. Paraguayans have rankings of ethical companies and exploitative workplaces, tolerance awards, trustworthiness scores, integrity thresholds, and quantitative indicators of CSR, cruelty, individual suffering, and collective misery, which judges and legislators regularly appeal to. Uruguayans don't think these moral properties - unlike physical properties such as albedo or density — can be rank-ordered, let alone quantitatively expressed or grasped (cf. Espeland/Sauder 2016; Sauder/Espeland 2009; Fourcade/Healy 2013; Norman et al. 2009: 260; 266-267). Alternatively, perhaps people in Paraguay don't speak of exploitation (or tolerance, discrimination, misery, etc.) very much. It's not a widespread idea in their society; most people do understand what it is, but it sounds odd or unnatural to them. Or, even more, they might not have a concept of exploitation at all; they might have never heard of it. If any of these second-order conditions obtained, their first-order consequence would be that E. A. (1922). "A Simple Code of Business Ethics." Annals of the American Academy of Political and Social Science 101: 223-228; Jenks, J. W. (1907). "The Modern Standard of Business Honor.” Publications of the American Economic Association, 3rd series, Vol. 8, No. 1, pp. 1-22; Marchand 1998: $174 f$. 
Uruguayans and Paraguayans couldn't have a meaningful discussion about exploitation. If diverging conceptualizations obtained, they would talk past one another. If the condition obtaining were a society's lacking a concept of exploitation at time $t$, a discussion about it couldn't occur.

For now, put these potential failures aside, and imagine that Uruguayans and Paraguayans do have an intercultural discussion going about exploitation (say, the exploitation of migrant workers in the United Arab Emirates or in a given factory in Montevideo), about tolerance (say, the conditions under which it's a virtue), or about historically discriminated groups and affirmative action (say, what minorities should qualify and what they should get). They do conceptualize exploitation, tolerance, and discrimination in reasonably similar ways. But do they use the same methods to address the moral questions under scrutiny? Unfortunately, they don't. They can't agree on what counts as relevant evidence, what counts as a good moral argument, and what counts as a moral argument at all (as opposed to some other kind of argument or an irrelevant consideration). Alternatively, Uruguayans and Paraguayans may not agree on what objects are capable of being morally evaluated in the first place. In Uruguay, dogs, pigs, children, groups, and corporations can be moral agents and have moral status. In Paraguay, only adult human beings have moral agency and status, and are therefore morally accountable (provided they are mentally sane, per their conception of mental sanity). Paraguayans find it insane that pigs, children, or corporations be said to be responsible, virtuous, or vicious.

Finally, the "grounding" of morals views, actions, and institutions constitutes another moral background dimension. For example, what reason do you or your company have to be moral (besides fear of legal punishment)? What makes morally good actions good and morally wrong actions wrong? At times, individuals, groups, and organizations are socially compelled to produce such reasons or grounds. What ethical and metaethical theories are they based on (cf. Anteby 2016; Anteby/Anderson 2016; Massengill 2013)? Babette and Gottlieb agree that corporations have environmental responsibilities and killing animals for food is morally impermissible. Yet, their reasons are at variance. Babette's reasons are nonhuman animals' rights, along with humans' duty not to harm nature and not to kill. By contrast, Gottlieb is trying to maximize happiness for the greatest number, which comprises future generations and all sentient beings. Neither Gottlieb nor Babette know much philosophy (they are after all in the hair-care industry), so they wouldn't understand the fancy-sounding words "consequentialist" and "deontological." But we do understand fancy-sounding words, are not in the hair-care industry (at least I am not), and know that his approach is consequentialist and hers is deontological.

None of these differences are about first-order moral beliefs or norms, even if they do have first-order consequences. Rather, they belong to the moral background or secondorder level. More formally, the moral background is the set of second-order elements that facilitate, support, or enable first-order morality. It has six dimensions, each of which raises empirical questions for research about morality-including but obviously not limited to research about business ethics and CSR. Thus, these questions outline a research program on moral background variations across time and place: 
1. Grounding. Given society $S$ at time $t$, what kinds of reasons do individuals and organizations use to support moral views and actions? What kinds of ethical and metaethical theories are these reasons based on?

2. Conceptual repertoire. What moral concepts are available to individuals and organizations? What concepts do they use frequently and successfully?

3. Object of evaluation. What can and can't be morally evaluated?

4. Method and argument. How do you go about asking and answering moral questions? What's a valid and invalid moral method? What's a persuasive and unpersuasive moral argument?

5. Metaethical objectivity. Is morality taken to be capable of objectivity? Or, rather, is morality a matter of subjective opinion or taste?

6. Metaphysics. What metaphysical assumptions underlie first-order morality? What are the socially prevalent understandings about what there is in the world, what these things are like, and what human beings are like?

The relationship between first-order morality and the second-order background isn't causal, which would entail temporal priority. Very roughly, I'm talking about something like conditions of possibility, so this is a priority of another kind. For instance, the fact that the concept of dignity happens to exist in our society doesn't cause judgments or norms about dignity, but enables them. Moral beliefs, judgments, norms, actions, understandings, and institutions-people's moral lives and societies' moral processesare made possible by the moral background.

Sociologists, anthropologists, behavioral economists, experimental philosophers, psychologists, neuroscientists, and others have increasingly turned their attention to morality. They have conducted many empirical studies about the first-order normative level and the first-order behavioral level. But almost no research has been conducted about the moral background. I argue that our scientific understanding of morality is hence deficient, because it fails to notice this literally fundamental level. To use an evocative but not perfectly accurate metaphor, the moral background sets the stage for moral life. It'd be even less accurate to speak of a first act that precedes a second act, and scholars of morality who arrive to the theater only for the latter-as I myself did, but maybe shouldn't have (Abend 2014: 31). I've now come to prefer a slightly different theatrical metaphor. The performance of a piece is made up of a set of practices. The background provides material and cultural elements that enable their success and intelligibility. They comprise: the script; people who have specific capabilities and dispositions (actors, directors, stage designers, costume designers, wardrobe supervisors, makeup artists, electricians, stagehands, house management staff, etc., and the audience); material objects (props, costumes, lights, scenery, the stage and the theater itself, etc.); and cultural understandings that make the piece intelligible. These things are already in place when the grand drape is raised.

That said, I'm in some respects unsure or unclear about this theatrical conditions-ofpossibility metaphor. For one, there are disanalogies. Plus, it might encompass too much. Should it encompass what actors need to survive (oxygen, water, food, apparently cigarettes), which obviously makes it possible that they play? In addition, if rehearsals 
enable the piece's successful performance, a tricky slippery slope looms: actors' having obtained skills in drama school without which they couldn't perform, their having attended elementary school, and so on. Last, my dichotomous classification might not always work. For example, I'm unsure where the lights and illumination belong: firstorder performance level, second-order conditions-of-possibility level, or both?

\section{VIII}

The moral background is a tool for empirical research. Since the proof of the pudding is in the eating, The Moral Background shows how this approach advances business ethics and CSR scholarship. As it turns out, "one important part of the history of business ethics is invisible to studies about first-order morality. What is most remarkable about this history is that so much normative continuity and consensus is underlain by divergent moral background elements. Therefore, the eye must be conceptually prepared to perceive these differences." Then, armed with the suitable conceptual tools, "I identify and analyze two types of moral background - the Standards of Practice and the Christian Merchant types. (...) Each type is characterized by a distinct pattern of values on the six moral background dimensions."

This table summarizes the two types (Abend 2014: 21, 261f.):

\begin{tabular}{|c|c|c|c|}
\hline $\begin{array}{l}\text { Background } \\
\text { Dimension }\end{array}$ & Specific Variable & $\begin{array}{c}\text { Christian Merchant } \\
\text { Type }\end{array}$ & $\begin{array}{l}\text { Standards of } \\
\text { Practice Type }\end{array}$ \\
\hline - Grounding & - Why be moral? & $\begin{array}{l}\text { Because it is right, } \\
\text { love of righteous- } \\
\text { ness, love of God } \\
\text { - Omniscient being } \\
\text { knows motives } \\
\text { - It will pay in hereaf- } \\
\text { ter }\end{array}$ & $\begin{array}{l}\text { - Because it will pay } \\
\text { the individual busi- } \\
\text { nessperson, Ameri- } \\
\text { can Business, and } \\
\text { American society }\end{array}$ \\
\hline $\begin{array}{l}\text { - Grounding } \\
\text { \& method } \\
\text { and argu- } \\
\text { ment }\end{array}$ & - Moral theory & $\begin{array}{l}\text { - Both deontology } \\
\text { and (in one particu- } \\
\text { lar context) } \\
\text { consequentialism }\end{array}$ & - Consequentialism \\
\hline $\begin{array}{l}\text { - Object of } \\
\text { evaluation }\end{array}$ & - Object & $\begin{array}{l}\text { - Both ethics of being } \\
\text { and ethics of doing }\end{array}$ & - Only ethics of doing \\
\hline $\begin{array}{l}\text { - Object of } \\
\text { evaluation }\end{array}$ & $\begin{array}{l}\text { - Main ethical } \\
\text { questions }\end{array}$ & $\begin{array}{l}\text { - What ought I to be? } \\
\text { - How does business } \\
\text { fit in this life? }\end{array}$ & $\begin{array}{l}\text { - What ought I to do? } \\
\text { - What is the ethical } \\
\text { "decision" in this } \\
\text { particular case? }\end{array}$ \\
\hline $\begin{array}{l}\text { - Method and } \\
\text { argument }\end{array}$ & - Evidence & $\begin{array}{l}\text { - Bible, theology } \\
\text { - Anecdotes }\end{array}$ & $\begin{array}{l}\text { - Science, empirical } \\
\text { data } \\
\text { - Anecdotes }\end{array}$ \\
\hline
\end{tabular}




\begin{tabular}{|c|c|c|c|}
\hline $\begin{array}{l}\text { - Method and } \\
\text { argument }\end{array}$ & $\begin{array}{l}\text { - Kind of } \\
\text { arguments }\end{array}$ & $\begin{array}{l}\text { - Metaphysical argu- } \\
\text { ments } \\
\text { - Biblical exegesis }\end{array}$ & $\begin{array}{l}\text { - Empiricism, induc- } \\
\text { tivism, and scientism } \\
\text { - Case method and } \\
\text { decision }\end{array}$ \\
\hline $\begin{array}{l}\text { - Repertoire } \\
\text { of concepts }\end{array}$ & $\begin{array}{l}\text { - Key business } \\
\text { ethics concepts }\end{array}$ & $\begin{array}{l}\text { - Golden Rule, } \\
\text { service }\end{array}$ & $\begin{array}{l}\text { - Golden Rule, ser- } \\
\text { vice, profession }\end{array}$ \\
\hline $\begin{array}{l}\text { - Repertoire } \\
\text { of concepts }\end{array}$ & $\begin{array}{l}\text { - Kind of } \\
\text { concepts }\end{array}$ & $\begin{array}{l}\text { - Theoretical } \\
\text { - Theological }\end{array}$ & $\begin{array}{l}\text { - Scientistic } \\
\text { - Professional }\end{array}$ \\
\hline $\begin{array}{l}\text { - Metaethical } \\
\text { objectivity }\end{array}$ & $\begin{array}{l}\text { - Truth-aptness } \\
\text { of morality }\end{array}$ & $\begin{array}{l}\text { - Generally yes, } \\
\text { absolute terms }\end{array}$ & $\begin{array}{l}\text { - Generally yes, some- } \\
\text { times relativist terms }\end{array}$ \\
\hline - Metaphysics & $\begin{array}{l}\text { - Elements in } \\
\text { metaphysical } \\
\text { picture }\end{array}$ & $\begin{array}{l}\text { - God } \\
\text { - God's ownership of } \\
\text { creation } \\
\text { - God's omniscience } \\
\text { - Heart and soul } \\
\text { - Two kinds of time }\end{array}$ & $\begin{array}{l}\text { - Scientific naturalism } \\
\text { - Secular time }\end{array}$ \\
\hline
\end{tabular}

Table 1: Two types of moral background (Source: after Abend, The Moral Background: 262)

Spelling out and providing empirical support for these differences is a laborious undertaking, which The Moral Background carries out (hopefully reasonably successfully). Here I wish instead to elaborate on one facet of the moral background to which I didn't pay sufficient attention. Comparative research about business ethics and CSR might especially benefit from it.

\section{IX}

Suppose your niece Elena tells you that she's currently facing a moral dilemma or problem, or that she has strong moral reasons to do something she doesn't feel like doing. What makes Elena's dilemma, problem, or reasons moral ones? Surely there are nonmoral reasons, problems of other kinds, and dilemmas that have nothing to do with morality. Why exactly should these be referred to as moral? This is an old philosophical problem: how to define, conceptualize, or demarcate morality, or how to distinguish moral from non-moral stuff (cf. Dworkin 1966; Falk 1960; 2008; Foot/Harrison 1954; Frankena 1958; 1963; 1970; 1980; MacIntyre 1957; Taylor 1978; Wallace/Walker 1970). In other words, what the defining or essential features of morality, moral action, moral decision, moral judgment, moral principles, moral rules, and moral norms are. For this purpose, "morality" covers "both 'moralness' and 'immoralness' (...), much as 'temperature' is used to cover heat and cold" (Frankena 1970: 147); the opposite of moral isn't immoral, but non-moral.

That's basically the philosophical question of what morality is. My moral background approach turns it into the empirical question of what morality is culturally and institutionally taken to be. How do particular societies and groups demarcate the domain of the moral? How are the "boundaries" (Gieryn 1999; Lamont/Molnár 2002) between 
morality and prudence, morality and convention, and morality and etiquette drawn and institutionalized? How do organizations and the law define, formalize, implement, negotiate, and police such demarcation criteria? How do these boundaries change over time? Likewise, given an organizational field, group, network, or society, what counts as a moral issue, rather than a religious, political, legal, aesthetic, culinary, philosophical, or sociological issue? What makes an issue a moral one, rather than an issue of taste, preference, or lifestyle on the one hand, or an issue of convenience and expediency on the other?

Thus conceived, demarcation isn't a first-order morality matter, but a dimension of the underlying moral background. ${ }^{68}$ Consider a few illustrations of the distinction. Firstorder sociological, anthropological, or historical projects might investigate norms concerning same-sex marriage; cohabitation; profanity, obscenity, or racism in artworks; pornography; pedophilia; honor; humor; selling weapons, blood, kidneys, slaves, or babies; or selling wives for "two shillings and sixpence" or just "a glass of ale" (Thompson 1991: 415). Or they might investigate prevalent views about people's and organizations' environmental practices; waste management; the state's subsidizing subsistence commodities; negotiators', lawyers', and advertisers' massaging the truth; your eating chicken; your weight; killing mice, mosquitos, or plants; smoking tobacco or hashish; sartorial choices; or leaving your hat on at the dinner table. Or they might investigate people's beliefs about the acceptability and desirability of companies' doing business with criminal dictators; raising the price of bread or scarce commodities; or paying hourly wages of $\$ 7.25$ or, if there's no legal minimum, $\$ 0.25$.

A moral background perspective raises a different research question: do these issues count as moral issues at all in particular societies and groups (be it primarily or to some extent)? Variation will presumably emerge. In some places and times, moral considerations aren't taken to apply to an artist's work; humor; market transactions ("business is business," anything can be bought and sold; there's no such thing as "profiteering"); whether you work hard or not; whether you work out or not; what and how much you eat or smoke; what shoes you wear; whether you brush your teeth twice a day; or what you do with your garbage or with your hat. Instead, they might be taken to be conventional domains (Huebner et al. 2010; Kelly et al. 2007; Turiel 1983); legal domains (if in country $C$ there isn't a law against $F$, you have no independent moral reason not to $F$ ); prudential domains; or realms of personal preference, taste, lifestyle, or custom. In some other places and times, those questions do belong to the moral domain; moral reasons are relevant and can't be put aside. Moreover, morality may be taken to be only one part of a larger whole. So my moral background approach asks, too, how moral considerations, norms, and institutions interact with other considerations, norms, and institutions.

\section{$\mathbf{X}$}

Apparently, a moral background project about the demarcation of morality can be normatively neutral and therefore orthogonal to all metaethical and philosophical troubles.

68 In The Moral Background demarcation isn't a separate dimension, though. Instead, it's briefly discussed in relation to two other dimensions (conceptual repertoires and object of evaluation). 
Apparently, a social scientist can and should be agnostic: she needn't have any stance on what morality really is; she just needs to find out what other people take morality to be (Durkheim 1982: 159). Her account can be neutral in the usual scientific way, and avoid her own biases and ethnocentric premises (cf. Lukes 2008). Yet, upon closer inspection, this seemingly comfortable position isn't all that comfortable.

This thought experiment shows why. Imagine a social scientist—call her Becky-who administers a survey questionnaire to a statistically representative sample of the Uruguayan population. One question is this:

To what extent would you consider these decisions to implicate moral considerations?

1. Whether to anonymously give half of your monthly income to a charitable organization (where these donations aren't tax deductible).

2. Whether your company should hire and promote more women, ethnic minorities, and people with disabilities.

3. Whether to wear a brown or a white shirt to work

Something like 90 percent of the sample answers that scenario (3) implicates moral considerations "very much," but scenarios (1) and (2) "not at all." What should Becky make of these results? Two possibilities present themselves. Interpretation $I_{1}$ is that Uruguayans' beliefs about what morality comprises are very different from ours. Puzzlingly so. Interpretation $I_{2}$ is that Uruguayans don't use the word "morality" as we do. When they utter "morality" they mean roughly what we mean when we utter "etiquette" or "good taste." If so, Uruguayans' demarcation of morality from etiquette would be exactly like ours: charity and affirmative action don't have to do with etiquette or good taste, but shirtcolor choice does. When Uruguayans do want to talk about morality, they have another word, which means just what we mean by "morality." The survey questionnaire took equal lexical meaning for granted, but this is no more warranted than taking equal beliefs about morality for granted. Neither can be assumed a priori.

One additional specification makes the challenge even more challenging. I forgot to mention that, unlike Americans and other civilized peoples, Uruguayans don't speak any English. Then, Becky may come up with Interpretation $I_{3}$ : there's an error in her English-Uruguayese dictionary, and hence in her translated questionnaire. Perhaps the lexicographers who wrote it thought the Uruguayese word "recoba" meant "morality," but in reality it means "etiquette." If so, Interpretation $I_{i}$ 's enormous cultural difference in the demarcation of morality would turn out to rest on a semantic mistake.

Which interpretation is most reasonable? How can Becky tell if her Uruguayan subjects are talking about morality or not (whatever word they happen to use)? My thought experiment illustrates Donald Davidson's (1984) argument about the interconnectedness of meaning and belief. Only if you know for sure the meaning of the words someone used can you figure out with certainty what her belief is, and only if you know for sure what her belief is can you figure out with certainty the meaning of the words she used.

Being an open-minded U.S. social scientist, Becky wanted to be agnostic about what morality is; she wanted to stand outside of morality altogether. It follows from Davidson's argument that this sort of agnostic standpoint doesn't exist. She must have a demarcation criterion of her own, which tells her what will and won't count as morality, 
moral issues, and moral stuff in her investigation. Otherwise, she would have no grounds to affirm that her research is about morality. Nor could she "arrive at comparative or general statements" about morality, which build on other people's work (Tavory 2011: 272). Becky's criterion can't be the use of the English word "morality" only (or words in other languages that a dictionary translates as "morality"). For this criterion wouldn't suffice to establish if she was collecting empirical data about the right kind of stuff. She could be investigating morality in the United States and etiquette in Uruguay.

\section{XI}

It might turn out that, after all, the decision about shirt color is a moral decision in Uruguay. It would be so if Becky discovered that Uruguayans had a foundational narrative, myth, or sacred text in which the color of the shirt you wear to work is related to human flourishing, the meaning of life, the life worth living, or laws given by their deities. Yet, notice why this discovery would vindicate Uruguayans' belief. It's not because Becky is open to any difference whatsoever in what morality is, but because human flourishing, the meaning of life, what is the life worth living, and divine laws fall under her demarcation criterion. These are not etiquette issues but moral issues according to her and by her standards. That's how her society tells morality from etiquette. ${ }^{69}$ Then, Becky can happily accept her subjects' claim that the choice of shirt color is a moral one. By contrast, suppose Uruguayans had no such narrative or myth, and in some follow-up in-depth interviews they kept talking about shirt-color choice in terms of what would be in bad taste, awkward, shock their older co-workers, or make them uncomfortable. In this situation, Becky would seem forced to conclude that they are indeed talking about etiquette- even if the adjective they used in Uruguayese to describe their choice were a cognate of the English word "moral," or even if (for the sake of the argument) they did speak in English and the word they actually used was "moral" (Abend 2008b).

In sum, Becky has to start with some criterion to demarcate morality. However, it doesn't follow that this demarcation criterion prevents, within the limits it sets, the investigation of variations in demarcation-of-morality criteria across time and place. I think there's a middle way or "golden mean" here (cf. Tavory 2011). The choice isn't dichotomous: either conceptual and semantic anarchy (any use of the word "morality" is as good as any other), or a rigid stipulation. For Becky's criterion needn't categorically establish the necessary and sufficient conditions for membership in the class of moral things. Nor does it need to commit her to a strict formal or logical test, e.g., Hare's (1972) universalizability. Nor does it need to impose any substantive restriction on what morality comprises, e.g., what kinds of practices or claims.

This is just a sketch of the problem. In order to be more precise, the following distinction can be a good starting point. If you hold that "( $\mathrm{m}$ )oral rules and principles are to be defined by reference to their content," you have three options: "It may be said first that a moral rule of principle is such because it mentions, as good or bad, right or wrong, certain kinds of actions. Secondly, it may be said that a rule or principle is a moral rule or principle if its holder justifies it by appealing to considerations of certain kinds. Thirdly, it may be said that moral rules and principles are to be characterized by reference to their being rules or principles with a certain kind of purpose" (Wallace/Walker 1970: 16). 
Instead, it might be enough for Becky to establish a more general group of concerns or projects, which have family resemblances, and with which morality must somehow have to do-say, the life well lived, or not misspent; respect, sympathy, and care for one's fellows; how to live together; or that which gives rise to "reactive attitudes," such as resentment, gratitude, or indignation (Lukes 2010; Strawson 2003). I do realize that this list is far from being Becky's solution: it's unclear why these four items constitute the relevant group, and whether it's a conjunction or disjunction (as "or" seems to suggest). Plus, something's "having to do with" something else is a vague relationship. More important, I do realize that these four more general concerns and projects aren't neutral vis-à-vis first-order moral claims and theories, and that they are shaped by the social scientist's own worldview or way of life. But my argument can grant that much. The social scientist's demarcation-of-morality criterion will be quite inclusive, but it will still exclude some things that would be unreasonable to call "moral" (to be sure, according to what seems to her unreasonable). That's the first, methodological step, which concerns the social scientist's establishing her object of inquiry. This leaves room for variation across societies in what morality is and what counts as moral. That's the second, empirical step, which concerns the social scientist's observations of the social world.

Thus, I disagree with Mrs. Foot's point about "content restrictions":

"In early versions of these theories (non-cognitivist metaethical theories) it was suggested that only a demand for consistency set any limits on the classes of actions to which words such as 'morally good' or 'morally bad' could be applied. (...) Thus, these early theories were radically subjectivist, allowing the possibility even of bizarre so-called 'moral judgments' about the wrongness of running around trees right-handed or looking at hedgehogs in the light of the moon... Nowadays it is commonly admitted, I believe, that there is some content restriction on what can intelligibly be said to be a system of morality." (Foot 1995: 2f.)

Contra Mrs. Foot, I believe that there can be moral judgments like these, provided that looking at hedgehogs in the light of the moon stands in the right kind of relationship to that more general group of concerns or projects, however selected (cf. Wallace/Walker 1970). Much like Uruguayans' shirt-color choices, in Paraguay looking at hedgehogs is a constitutive component of the good life; Paraguayans attach much existential meaning to that activity and its proper practice. On my view, there are some restrictions, but they aren't about the content of the practice, judgment, belief, institution, and so on. ${ }^{70}$

However, elsewhere Foot argues as follows: "Suppose for instance that someone said, 'One should never step on the lines on a pavement; it is important to walk inside the squares,' or 'It is not right to wear brightly coloured clothes,' and suppose that in either case we saw him most conscientiously following his principle, trying to get other people to do the same, thinking that he should be blamed if he failed, and refusing to allow that he could escape from the rule by giving up some aim such as not straining his heart, or being well dressed. This is not enough to make these principles into moral principles; they seem too queer, and, still more, too isolated, to play the role." Now, things look differently "if we suppose a certain background": “"one should not wear bright colours' begins to look as if it might be a moral principle if we think of a man with a Quaker outlook, or simply of one who sees wearing bright colours as ostentation." Unlike wearing bright colors, Foot believes that in the stepping-on-lines case "it is hard to know what the background could be" (Foot/Harrison 1954: 104f., 110). I don't understand why. 
All in all, moral background investigations may examine variations in the demarcation of morality; they may examine how its boundaries are differently drawn in different societies and historical epochs. This empirical project does seem defensible. Yet, on pain of conceptual incoherence, these researchers will have to start with their own demarcation. While their criterion might be broad and lenient, they should be aware of its being shaped by their understanding of the concept of morality-be it based on the Oxford English Dictionary, their favorite philosophers, sociological and anthropological research, methodological tractability, unconscious cultural influences, or whatever. In any case, this couldn't be otherwise. Any conceptual choice will entail certain commitments and perspectives rather than others. The neutrality of "the absolute conception of the world" or "viewpoint of no-one in particular" isn't available to human beings (Fine 1998; Nagel 1986; 1997; Williams 1978). So we must make do with our limited capacities and epistemic perspectives. We are often left with nothing but reasonableness: what seems to me reasonable, as far as I can see. Luckily, accepting these cognitive limitations can be epistemologically and morally liberating (Dworkin 1996; Lukes 2016).

\section{XII}

Historical research about business ethics and CSR at the first-order level-both firstorder normative and first-order behavioral-is important. It can bring to light important facts and processes, and thereby rectify mistaken beliefs about the unique and unprecedented nature of the present—-be it the Enron, Tyco, and WorldCom scandals, the "new role" of business today, what's today "more and more" the case, the latest call to take stakeholders' interests into account, or the latest call to reform business ethics education. Such historical knowledge can in turn be practically and politically useful. It can help attune policies to a society's trajectories, experiences, and self-understandings, and help prevent that wheels be reinvented. Nevertheless, historical research about the first-order level is likely to keep showing the broader patterns we are already familiar with. In fact, the time might be ripe for comparative questions about first-order patterns and processes in business ethics history, e.g., if capitalist societies always manifest them in a similar manner. At the same time, though, historical researchers should continue to provide detailed, in-depth accounts about different places and times. Studies about how supposedly familiar first-order patterns unfold and play out may reveal dissimilarities of theoretical significance. They will at any rate fill gaps in our historical knowledge.

Historical research about business ethics and CSR at the moral background level has another aim in view: our understanding of society, morality, and the moral foundations of capitalist societies. For the moral background points to a peculiar feature of social phenomena: they have cultural and institutional conditions of possibility. If conditions $C_{1}$ and $C_{2}$ didn't obtain in society $S$, phenomenon $P$ couldn't possibly exist. This is true even of one individual's "behavior." For instance, her bodily movements don't suffice to determine what she is doing-more technically, they don't suffice to individuate or pick out her action. ${ }^{71}$ This is a fortiori true of people's moral life and societies' moral processes.

71 Cf. Anscombe (1979; 2000); Davidson (1980); Geertz (1973); Lukes (1985); Ryle (2009); Taylor (1964; 2004); Velleman (2013). 
For instance, people might make claims about a business community's integrity, humanness, materialism, or honor. Or a society might have beliefs, norms, and laws concerning industriousness, gentlemanliness, decency, dignity, petty behavior, or fanatic beliefs. These properties are "thick" (Kirchin 2013; Williams 1985). In order for materialism, gentlemanliness, fanaticism, or humanness to even exist and make sense in a society, certain cultural and institutional conditions must be in place. Differently put, thick concepts are ontologically dependent on cultural and institutional facts (Abend 2011). Which suggests a fundamental difference between the typical objects of social science and the typical objects of natural science. In this sense, a science whose object is morality will differ from a science whose object is the behavior of bees, neurotransmitters, or galaxies. More generally, social scientists can investigate the causes of phenomena, but they should also investigate their conditions of possibility. What features of the social world make phenomenon $P$ or object $O$ possible? This question might be called "transcendental," despite its empirical character and its diverging from epistemologists' conditions of possibility (cf. Brueckner 1983; 1984; Stroud 1968; Cassam 2007). In The Moral Background I identified six background dimensions, which guided my historical narrative and typology. In this article I've argued that the same conceptual framework can guide comparative and historical research about the demarcation of morality (in business ethics and elsewhere): what issues and questions belong to the moral domain in society $S$ at time $t$, diachronically, how issues and questions enter and leave the moral domain; and what social forces, institutions, ideas, and interests play a role in these historical processes. As regards ethics and economics, you may investigate whether, how, where, and when the following three trends coexist, and the practical and political conflicts they lead to. First, organizational, cultural, and political efforts to safeguard the boundaries of the market or the economic sphere, as an autonomous domain that follows its own "rationality" or "logic," which shouldn't be tampered with. Second, organizational, cultural, and political efforts to institutionalize the view that morality does apply in economic life, and capitalism and ethics aren't incompatible (including efforts to obtain social, cultural, organizational, and financial resources to help institutionalize it). Third, organizational, cultural, and political efforts to do away with the very idea that societies consist of distinct domains, spheres, or "logics." 72

Last but not least, future research may ask what moral background properties are intrinsic to capitalism and what properties are contingent and vary. What accounts for moral background differences and change? Might there be varieties of capitalism vis-àvis the moral background?

\section{References}

Abend, G. (2008a): A Genealogy of Business Ethics, PhD Dissertation, Department of Sociology, Evanston: Northwestern University.

Abend, G. (2008b): Two Main Problems in the Sociology of Morality, in: Theory and Society, Vol. 37/No. 2, 87-125.

72

See, e.g., Beschorner (2013a; 2013b); Fourcade/Healy (2007); Habermas (1984; 1987); Hausman (1989); Lukes (2005; 2016); Sandel (2012); Ulrich (2008); Zelizer (2005; 2007; 2011). 
Abend, G. (2011): Thick Concepts and the Moral Brain, in: European Journal of Sociology, Vol. 52/No. 1, 143-172.

Abend, G. (2013): The Origins of Business Ethics in American Universities, 1902-1936, in: Business Ethics Quarterly, Vol. 23/No. 2, 171-205.

Abend, G. (2014): The Moral Background: An Inquiry into the History of Business Ethics, Princeton: Princeton University Press.

Acquier, A./Gond, J. P./Pasquero, J. (2011): Rediscovering Howard R. Bowen's Legacy, in: Business \& Society, Vol. 50/No. 4, 607-646.

Anscombe, G. E. M. (1979): Under a Description, in: Noûs, Vol. 13/No. 2, 219-233.

Anscombe, G. E. M. (2000/1963): Intention, 2nd ed., Cambridge, Massachusetts: Harvard University Press.

Anteby, M. (2013): Manufacturing Morals, Chicago: University of Chicago Press.

Anteby, M. (2016): The Ideology of Silence at the Harvard Business School, in: Burton, D./Cohen, L./Lounsbury, M. (Eds.): Research in the Sociology of Organizations (forthcoming).

Anteby, M./Anderson, C. (2016): Management and Morality: The Elusive Corporate Morals, in: Wilkinson, A./Armstrong, S./Lounsbury, M. (Eds.): Oxford Handbook of Management, Oxford: Oxford University Press (forthcoming).

Avi-Yonah, R. S. (2005): The Cyclical Transformation of the Corporate Form, in: Delaware Journal of Corporate Law, Vol. 30, 767-818.

Berman, M. (1982): All That Is Solid Melts into Air, New York: Simon and Schuster.

Beschorner, T. (2013a): Creating Shared Value: The One-Trick Pony Approach, in: Business Ethics Journal Review, Vol. 17/No. 1, 106-112.

Beschorner, T. (2013b): Kulturalistische Wirtschaftsethik. Grundzüge einer Theorie der Anwendung, in: Zeitschrift für Wirtschafts- und Unternehmensethik, Vol. 14/No. 3, 346-372.

Boltanski, L./Chiapello, E. (1999): Le nouvel esprit du capitalisme, Paris: Gallimard.

Brueckner, A. (1983): Transcendental Arguments I, in: Noûs, Vol. 17/No. 4, 551-575.

Brueckner, A. (1984): Transcendental Arguments II, in: Noûs, Vol. 18/No. 2, 197-225.

Carroll, A. B. (1999): Corporate Social Responsibility: Evolution of a Definitional Construct, in: Business \& Society, Vol. 38/No. 3, 268-295.

Carroll, A. B. (2008): A History of Corporate Social Responsibility: Concepts and Practices, in: Crane, A./McWilliams, A./Matten, D./Moon, J./Siegel, D. S. (Eds.): The Oxford Handbook of Corporate Social Responsibility, Oxford, New York: Oxford University Press, 19-46.

Carroll, A. B./Lipartito, K. J./Post, J. E./Werhane, P. H./Goodpaster, K. E. (Eds.) (2012): Corporate Responsibility: The American Experience, Cambridge, UK: Cambridge University Press.

Cassam, Q. (2007): The Possibility of Knowledge, Oxford University Press.

Copeland, M. T. (1958): And Mark an Era: The Story of the Harvard Business School, Boston: Little, Brown and Company.

Cowing, C. B. (1965): Populists, Plungers, and Progressives, Princeton: Princeton University Press.

Cruikshank, J. L. (1987): A Delicate Experiment: The Harvard Business School, 1908-1945, Boston: Harvard Business School Press.

Cuff, R. (1996): Edwin F. Gay, Arch W. Shaw, and the Uses of History in Early Graduate Business Education, in: Journal of Management History, Vol. 2/No. 3, 9-25. 
Cumbler, J. T. (2000): Conflict, Accommodation, and Compromise: Connecticut's Attempt to Control Industrial Wastes in the Progressive Era, in: Environmental History, Vol. 5/No. 3, 314-335.

Damin, C. (1872/1871): The Descent of Man, and Selection in Relation to Sex, Vol. I, New York: D. Appleton and Company.

Davidson, D. (1980): Essays on Actions and Events, Oxford, New York: Oxford University Press.

Davidson, D. (1984): Inquiries into Truth and Interpretation, Oxford, New York: Oxford University Press.

Durkheim, É. (1982): The Rules of Sociological Method and Selected Texts on Sociology and its Method. Edited with an Introduction by Steven Lukes. Translated by W.D. Halls, New York: Free Press.

Dworkin, R. (1966): Lord Devlin and the Enforcement of Morals, in: Yale Law Journal, Vol. 75, 986-1005.

Dworkin, R. (1996): Objectivity and Truth: You'd Better Believe It, in: Philosophy and Public Affairs, Vol. 25/No. 2, 87-139.

Espeland, W. N./Sauder, M. (2016): Engines of Anxiety: Academic Rankings, Reputation, and Accountability, New York: Russell Sage.

Fairfield, R. P. (1950): Benjamin Orange Flower: Father of the Muckrakers, in: American Literature, Vol. 22/No. 3, 272-282.

Falk, W. D. (1960): Morality and Convention, in: The Journal of Philosophy, Vol. 57, 675-685.

Falk, W. D. (2008/1963): Morality, Self, and Others, in: Bloomfield, P. (Ed.): Morality and SelfInterest, New York: Oxford University Press, 225-250.

Filler, L. (1993): The Muckrakers, Stanford: Stanford University Press.

Fine, A. (1998): The Viewpoint of No-One in Particular, in: Proceedings and Addresses of the American Philosophical Association, Vol. 72/No. 2, 9-20.

Foot, P. (1995): Does Moral Subjectivism Rest on a Mistake?, in: Oxford Journal of Legal Studies, Vol. 15, 1-14.

Foot, P. R./Harrison J. (1954): Symposium: When Is a Principle a Moral Principle, in: Proceedings of the Aristotelian Society, Supplementary Volumes 28, 95-134.

Fourcade, M./Healy, K. (2007): Moral Views of Market Society, in: Annual Review of Sociology, Vol. 33, 285-311.

Fourcade, M./Healy, K. (2013): Classification Situations: Life-Chances in the Neoliberal Era, in: Accounting, Organizations and Society, Vol. 38, 559-572.

Frankena, W. K. (1958): MacIntyre on Defining Morality, in: Philosophy, Vol. 33/No. 125, 158-162.

Frankena, W. K. (1963): Recent Conceptions of Morality, in Castañeda, H.-N./Nakhnikian, G. (Eds.): Morality and the Language of Conduct, Detroit: Wayne State University Press, 1-24.

Frankena, W. K. (1970): The Concept of Morality, in: Wallace, G./Walker A. D. M. (Eds.) (1970): The Definition of Morality, London: Methuen, 146-173.

Frankena, W. K. (1980): Thinking about Morality, Ann Arbor: University of Michigan Press.

Frydman, C./Saks, R. (2010): Executive Compensation, in: Review of Financial Studies, Vol. 23, 2099-2138.

Frydman, C./Molloy, R. (2012): Pay Cuts for the Boss, in: Journal of Economic History, Vol. 72, 225-251. 
Geertz, C. (1973): Thick Description: Toward an Interpretive Theory of Culture, in: The Interpretation of Cultures, New York: Basic Books, 3-30.

Geisst, C. R. (2004): Wall Street: A History, New York: Oxford University Press.

Gieryn, T. F. (1999): Cultural Boundaries of Science, Chicago: University of Chicago Press.

Goffman, E. (1959): The Presentation of Self in Everyday Life, Garden City: Doubleday.

Goodpaster, K. E./Matthews, J. B. Jr. (2003/1982): Can a Corporation Have a Conscience?, in: Harvard Business Review on Corporate Responsibility, Boston: Harvard Business School Press, 131-155.

Habermas, J. (1984/1981): The Theory of Communicative Action, Vol. 1., translated by T. McCarthy, Boston: Beacon.

Habermas, J. (1987/1981): The Theory of Communicative Action, Vol. 2, translated by T. McCarthy, Boston: Beacon.

Hare, R. M. (1972): Essays on the Moral Concepts, Berkeley: University of California Press.

Hausman, D. M. (1989): Are Markets Morally Free Zones?, in: Philosophy and Public Affairs, Vol. 18/No. 4, 317-333.

Hays, S. P. (1959): Conservation and the Gospel of Efficiency, Cambridge, Massachusetts: Harvard University Press.

Heald, M. (1957): Management's Responsibility to Society: The Growth of an Idea, in: Business History Review, Vol. 31/No. 4, 375-384.

Heald, M. (1961): Business Thought in the Twenties: Social Responsibility, in: American Quarterly, Vol. 13/No. 2, 126-139.

Heald, M. (1988/1970): The Social Responsibilities of Business: Company and Community, 1900-1960, New Brunswick: Transaction Publishers.

Hoffman, R. C. (2007): Corporate Social Responsibility in the 1920s: An Institutional Perspective, in: Journal of Management History, Vol. 13/No. 1, 55-73.

Huebner, B./Lee, J. J./Hauser, M. D. (2010): The Moral-Conventional Distinction in Mature Moral Competence, in: Journal of Cognition and Culture, Vol. 10/No. 1-2, 1-26.

Husted, B. W. (2015): Corporate Social Responsibility Practice from 1800-1914: Past Initiatives and Current Debates, in: Business Ethics Quarterly, Vol. 25/No. 1, 125-141.

Jacoby, S. M. (1998): Modern Manors: Welfare Capitalism since the New Deal, Princeton: Princeton University Press.

Jones, G. (2013): Debating the Responsibility of Capitalism in Historical and Global Perspective, Harvard Business School, Working Paper 14-004.

Kaplan, R. (2015): Who Has Been Regulating Whom, Business or Society? The Mid-20th-Century Institutionalization of 'Corporate Responsibility' in the USA, in: Socio-Economic Review, Vol. 13, 125-155.

Kaufman, B. E. (2008): Managing the Human Factor, Ithaca: Cornell University Press.

Kelly, D./Stich, S./Haley, K. J./Eng, S. J./Fessler, D. M. T. (2007): Harm, Affect, and the Moral/Conventional Distinction, in: Mind \& Language, Vol. 22/No. 2, 117-131.

Khurana, R. (2007): From Higher Aims to Hired Hands, Princeton: Princeton University Press.

Kirchin, S. (Ed.) (2013): Thick Concepts, Oxford: Oxford University Press.

Krum, J. R./Greenbill, R. H. (1972): The Extent of Industry Self-Regulation Through Trade Association Codes of Ethics, in: Antitrust Bulletin Vol. 17, 379-393. 
Lamont, M./Molnár, V. (2002): The Study of Boundaries in the Social Sciences, in: Annual Review of Sociology, Vol. 28, 167-195.

Lipartito, K. (1995): Culture and the Practice of Business History, in: Business and Economic History, Vol. 24, 1-41.

Lipartito, K. (2004): The Utopian Corporation, in: Lipartito, K./Sicilia, D. B. (Eds.): Constructing Corporate America, Oxford, New York: Oxford University Press, 94-119.

Lukes, S. (1985): The Contradictory Aims of Action Theory, in: Seebaß, G./Tuomela, R. (Eds.): Social Action, Dodrecht, Boston: D. Reidel, 53-59.

Lukes, S. (2005): Invasions of the Market, in: Miller, M. (Ed.): Worlds of Capitalism, London, New York: Routledge, 289-312.

Lukes, S. (2006/1973): Individualism, Colchester: ECPR Press.

Lukes, S. (2008): Moral Relativism, New York: Picador.

Lukes, S. (2010): The Social Construction of Morality?, in: Hitlin, S./Vaisey, S. (Eds.): Handbook of the Sociology of Morality, New York: Springer, 549-560.

Lukes, S. (2016): Moral as a Political Concept, unpublished manuscript.

MacIntyre A. (1957): What Morality Is Not, in: Philosophy, Vol. 32/No. 132, 325-335.

Marchand, R. (1991): The Corporation Nobody Knew, in: Business History Review, Vol. 65, 825-875.

Marchand, R. (1998): Creating the Corporate Soul, Berkeley: University of California Press.

Marens, R. (2008): Recovering the Past: Reviving the Legacy of the Early Scholars of Corporate Social Responsibility, in: Journal of Management History, Vol. 14/No. 1, 55-72.

Marens, R. (2013): What Comes Around: The Early 20th century American Roots of Legitimating Corporate Social Responsibility, in: Organization, Vol. 20, 454-476.

Massengill, R. P. (2013): Wal-Mart Wars, New York: NYU Press.

McQuaid, K. (2003/1986): A Response to Industrialism, Washington, D.C.: Beard Books.

Nagel, T. (1986): The View from Nowhere, New York: Oxford University Press.

Nagel, T. (1997): The Last Word, New York: Oxford University Press.

Norman, W. (2004): Put an Ethicist on the Team!, in: Journal of Business Ethics Education, Vol. 1, 257-274.

Norman, W./Roux, C./Bélanger, P. (2009): Recognizing Business Ethics, in: Journal of Business Ethics, Vol. 86, 257-271.

Ott, J. C. (2009): 'The Free and Open People's Market', in: Journal of American History, Vol. 96, 44 71.

Ott, J. C. (2011): When Wall Street Met Main Street, Cambridge, Massachusetts: Harvard University Press.

Petre, C. (2015): The Social Life of Metrics, PhD Dissertation, Department of Sociology, New York: New York University.

Piper, T. R./Gentile, M. C./Parks, S. D. (1993): Can Ethics Be Taught? Perspectives, Challenges, and Approaches at Harvard Business School, Boston: Harvard Business School Press.

Reyerson, K. L. (1982): Commercial Fraud in the Middle Ages: The Case of the Dissembling Pepperer, in: Journal of Medieval History, Vol. 8, 63-73.

Rosa, H. (2005): Beschleunigung: Die Veränderung der Zeitstrukturen in der Moderne, Frankfurt a. M.: Suhrkamp.

Rosen, C. M. (1995): Businessmen against Pollution in Late Nineteenth Century Chicago, in: Business History Review, Vol. 69, 351-397. 
Ryle, G. (2009/1968): The Thinking of Thoughts: What Is 'le Penseur' Doing?, in: Collected Essays 1929-1968, New York: Routledge, 494-510.

Sandel, M. (2012) What Money Can't Buy, New York: Farrar, Straus and Giroux.

Sauder, M./Espeland, W. N. (2009): The Discipline of Rankings, in: American Sociological Review, Vol. 74, 63-82.

Seavoy, R. E. (1978): The Public Service Origins of the American Business Corporation, in: Business History Review, Vol. 52, 30-60.

Seavoy, R. E. (1982): The Origins of the American Business Corporation, 1784-1855, Westport: Greenwood Press.

Shamir, R. (2004): Between Self-Regulation and the Alien Tort Claims Act, in: Law \& Society Review, Vol. 38/No. 4, 635-664.

Shamir, R. (2010): Capitalism, Governance, and Authority, in: Annual Review of Law and Social Science, Vol. 6, 531-553.

Spector, B. (2006): The Harvard Business Review Goes to War, Management \& Organizational History, Vol. 1/No. 3, 273-295.

Spector, B. (2008): 'Business Responsibilities in a Divided World': The Cold War Roots of the Corporate Social Responsibility Movement, in: Enterprise \& Society, Vol. 9/No. 2, 314-336.

Spector, B. (2015): Capitalist Ideologues and the Cold War 'Struggle for Men's Minds', in: McLaren, P. G./Mills, A. J./Weatherbee, T. G. (Eds.): The Routledge Companion to Management and Organizational History, Abingdon, New York: Routledge, 285-301.

Spender, J.-C. (2005): Speaking about Management Education, in: Management Decision, Vol. 43, 1282-1292.

Spender, J.-C. (2007): Management as a Regulated Profession, in: Journal of Management Inquiry, Vol. 16, 1-11.

Strawson, P. (2003/1962): Freedom and Resentment, in: Watson, G. (Ed.): Free Will, 2nd ed., New York: Oxford University Press, 72-93.

Stroud, B. (1968): Transcendental Arguments, in: The Journal of Philosophy, Vol. 65, 241-256.

Swanson, D./Fisher, D. (Eds.) (2011): Toward Assessing Business Ethics Education, Charlotte: Information Age Pub.

Tavory, I. (2011): The Question of Moral Action, in: Sociological Theory, Vol. 29, 272-293.

Taylor, C. (1964): The Explanation of Behaviour, New York: Humanities Press.

Taylor, C. (2004): Modern Social Imaginaries, Duke, London: Duke University Press.

Taylor, P. W. (1978): On Taking the Moral Point of View, in: Midwest Studies in Philosophy, Vol. 3, 35-61.

Thompson, E. P. (1991): Customs in Common, New York: Penguin Books.

Tone, A. (1997): The Business of Benevolence: Industrial Paternalism in Progressive America, Ithaca: Cornell University Press.

Turiel, E. (1983): The Development of Social Knowledge: Morality and Convention, Cambridge, UK: Cambridge University Press.

Ulrich, P. (2008/2001): Integrative Economic Ethics: Foundations of a Civilized Market Economy, translated by J. Fearns, Cambridge, UK: Cambridge University Press.

Velleman, J. D. (2013): Doables, in: Philosophical Explorations, Vol. 16/No. 3, 1-16.

Wallace, G./Walker A. D. M. (Eds.) (1970): The Definition of Morality, London: Methuen. 
Wells, C. A. H. (2002-2003): The Cycles of Corporate Social Responsibility: An Historical Retrospective for the Twenty-first Century, University of Kansas Law Review, Vol. 51, 77-140.

Wells, H. (2010): 'No Man Can Be Worth \$1,000,000 a Year': The Fight Over Executive Compensation in 1930s America, in: University of Richmond Law Review, Vol. 44, 689-769.

Williams, B. A. O. (1978): Descartes: The Project of Pure Enquiry, Hassocks: Harvester Press.

Williams, B. A. O. (1985) Ethics and the Limits of Philosophy, Cambridge, Massachusetts: Harvard University Press.

Windsor, D. (2004): A Required Foundation Course for Moral, Legal and Political Education, in: Journal of Business Ethics Education, Vol. 1/No. 2, 137-164.

Zelizer, V. (2005): The Purchase of Intimacy, Princeton: Princeton University Press.

Zelizer, V. (2007):. Ethics in the Economy, in: Zeitschrift für Wirtschafts- und Unternehmensethik, Vol. 8/No. 1, 8-23.

Zelizer, V. (2011): Economic Lives, Princeton: Princeton University Press. 